\title{
The Energy Investment Decision in the Nonresidential Building Sector: Research into the Areas of Influence
}
S. A. Harkreader
D. L. Ivey, Project Manager

April 1987

Prepared for the U.S. Department of Energy under Contract DE-AC06-76RLO 1830

Pacific Northwest Laboratory Operated for the U.S. Department of Energy by Battelle Memorial Institute 


\section{DISCLAIMER}

This report was prepared as an account of work sponsored by an agency of the United States Government. Neither the United States Government nor any agency thereof, nor Battelle Memorial Institute, nor any of their employees, makes any warranty, expressed or implied, or assumes any legal liability or responsibility for the accuracy, completeness, or usefulness of any information, apparatus, product, or process disclosed, or represents that its use would not infringe privately owned rights. Reference herein to any specific commercial procluct, process, or service by trade name, trademark, manufacturer, or otherwise, does not necessarily constitute or imply its endorsement, recommendation, or favoring by the United States Government of any agency thereof, or Battelle Memorial Institute. The views and opinions of authors expressed herein do not necessarly state or reflect those of the United States Government or any agency thereof, or Battelle Memorial Institute.

\section{PACIFIC NORTHWEST LABORATORY operated by \\ BATTELLE MEMORIAL INSTITUTE for the \\ UNITED STATES DEPARTMENT OF ENERGY under Contract DE-AC06-76RLO 1830}

\begin{tabular}{|c|c|}
\hline \multicolumn{2}{|c|}{$\begin{array}{l}\text { Printed in the United States of America } \\
\text { Available from } \\
\text { National Technical Information Service } \\
\text { United States Department of Commerce } \\
5285 \text { Port Royal Road } \\
\text { Springfield, Virginia } 22161\end{array}$} \\
\hline \multicolumn{2}{|c|}{$\begin{array}{l}\text { NTIS Price Codes } \\
\text { Microfiche A01 }\end{array}$} \\
\hline \multicolumn{2}{|c|}{ Printed Copy } \\
\hline Pages & $\begin{array}{l}\text { Price } \\
\text { Codes }\end{array}$ \\
\hline $001-025$ & $\mathrm{~A} 02$ \\
\hline 026-050 & $\mathrm{A} 03$ \\
\hline $051-075$ & A04 \\
\hline $076-100$ & A05 \\
\hline $101-125$ & A06 \\
\hline $126-150$ & $\mathrm{~A} 07$ \\
\hline $151-175$ & $A 0 B$ \\
\hline $176-200$ & $\mathrm{~A} 09$ \\
\hline $201-225$ & $\mathrm{~A} 010$ \\
\hline $226-250$ & A011 \\
\hline $251-275$ & A012 \\
\hline $276-300$ & A013 \\
\hline
\end{tabular}


THE ENERGY INVESTMENT DECISION IN THE NONRESIDENTIAL BUILDING SECTOR:

RESEARCH INTO THE AREAS OF INFLUENCE

S. A. Harkreader

D. L. Ivey, Project Manager

Apri 11987

Prepared for

the U.S. Department of Energy

under Contract DE-ACO6-76RLO 1830

Pacific Northwest Laboratory

Richland, Washington 99352 
SUMMARY

The emphasis of this report is on energy investments in the nonresidential building sector. It's purpose is to examine the energy investment market in terms of the areas which influence it and to suggest research projects that would aid in the planning of research and development agendas for the Office of Building and Community Systems (BCS). Knowledge of the areas that influence the energy investment decision is vital to projecting the state of the energy investment market. For example, an examination of regional population and employment trends identifies the Southeast and the Southwest regions of the country as hot spots for economic growth. Increased population and economic activity creates a demand for building construction in these areas. By having knowledge of trends such as this in advance, BCS could direct its research activities towards technologies that would be most useful.

A search of the literature revealed a number of areas that influence the energy investment market. The report discusses the physical characteristics of nonresidential buildings, legal environment for nonresidential buildings (ownership, organizational structure of owner, leasing arrangements), demographic trends, economic trends, organizational decision processes, and the role of decision maker attitudes.

Data on the physical characteristics of buildings and on the demographic and economic trends influencing the nonresidential building sector are avai?able from a number of sources. The Energy Information Administration produces statistics on the physical characteristics of buildings; type of building activity, building size, building age, and location. Data on physical characteristics of buildings would allow for planning of research for technologies that would be most appropriate. Building age identifies the size of the retrofit market, where as, building location identifies the climate constraints for new technologies. The U.S. Bureau of the Census produces statistics on demographic and economic variables which have an effect on the energy investment market. Some of these variables are age-specific population patterns, regional population growth patterns, and population migration patterns. Statistics are 
available on such economic variables as personal income, employment figures, foreign investments, building vacancy rates, interest rates, and number of new businesses, to name a few.

The literature also contains material on the buying and decision processes of organizational behavior, but no up-to-date databases identifying the decision makers in the nonresidential building sector or the attitudes associated with new technology acceptance were uncovered. Attitudinal data on decision makers is important. The use of new uproven technologies involves some amount of risk for the adopter. With this type of information, innovative decision makers (high risk personalities), can be identified and technology transfer programs designed to increase the penetration rate of new technologies. 0ther information that is lacking is an integrated source of physical building characteristics and the legal environment surrounding the buildings (type of ownership, organizational structure of owners, and leasing arrangements). These areas of influence can he explored with further research and aid BCS in identifying areas for research and more effectively transfer the fruits of their research to the private sector. The report also discusses the construction of scenarios that help to project the state of the energy investment market in Tight of the areas of influence mentioned. Scenario construction can be an important tool in planning for the future.

This report also identifies gaps in information that exist for the nonresidential building sector and suggests research projects that would be valuable in tracking and projecting the nonresidential energy investment market. The recommended projects include:

- tracking demographic and economic trends that affect the energy investment market

- characterizing the potential for energy investments in the nonresidential building sector

- characterizing the regional attitudinal composition of nonresidential energy investment decision makers

- exploring the relationship between specific attitudes and energy investments 


\section{CONTENTS}

SUMMARY

$i j i$

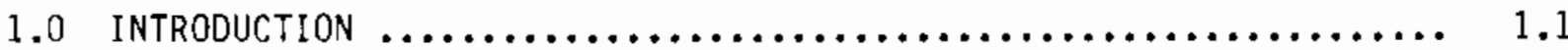

2.0 DESCRIPTORS INFLUENCING THE ENERGY INVESTMENT MARKET $\ldots \ldots \ldots \ldots \ldots .2 .1$

2.1 PhYSICAL DESCRIPTORS AFFECTING ENERGY INVESTMENTS $\ldots \ldots \ldots \ldots .2 .1$

2.2 LEGAL DESCRIPTORS AFFECTING ENERGY INVESTMENTS $\ldots \ldots \ldots \ldots \ldots .2 .2$

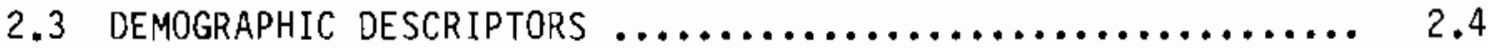

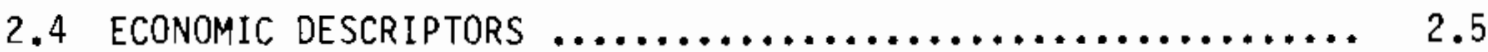

3.0 DESCRIPTORS OF ENERGY INVESTMENT DECISION MAKERS $\ldots \ldots \ldots \ldots \ldots \ldots . .1$

3.1 DECISION PROCESS DRIVERS AND INVESTMENT DECISION

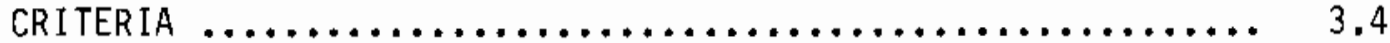

3.1.1 Building Ownership/0ccupancy ................ 3.4

3.1 .2 Building Use Mode $\ldots \ldots \ldots \ldots \ldots \ldots \ldots \ldots \ldots \ldots \ldots . \ldots \ldots$

3.1 .3 Construction-Contract Bid Mode $\ldots \ldots \ldots \ldots \ldots \ldots \ldots . . \ldots$

3.1.4 Energy Investment Decision Criteria ............ 3.7

3.2 ENERGY INVESTMENT DECISION MAKERS: ATTITUDES AND THE
DECISION PROCESS $\ldots \ldots \ldots \ldots \ldots \ldots \ldots \ldots \ldots \ldots \ldots \ldots \ldots \ldots \ldots \ldots$

3.2.1 The Decision Process $\ldots \ldots \ldots \ldots \ldots \ldots \ldots \ldots \ldots \ldots . . . \ldots \ldots$

3.2.2 Attitudes of Decision Makers .................. 3.9

4.0 MAKING PROJECTIONS OF THE NONRESIDENTIAL ENERGY INVESTMENT MARKET

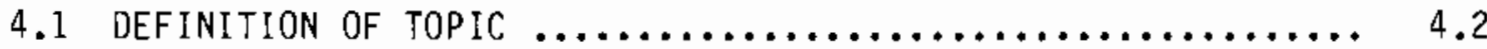

4.2 IDENTIFICATION OF THE AREAS OF INFLUENCE $\ldots \ldots \ldots \ldots \ldots \ldots \ldots .4 .3$

4.2 .1 Population Trends Examined ................. 4.3

4.2 .2 The Legislative Atmosphere $\ldots \ldots \ldots \ldots \ldots \ldots \ldots \ldots \ldots . . \ldots$

4.2 .3 Economic Trends Examined .................... 4.7

4.2 .4 Climatic Demands ....................... 4.9 
4.3 THE SCENARIO: THE ENERGY INVESTMENT MARKET IN THE MERCANTILE SERVICE, YEAR $2007 \ldots \ldots \ldots \ldots \ldots \ldots \ldots \ldots \ldots \ldots \ldots \ldots . \ldots . \ldots \ldots$

4.4 INTRODUCTION OF UNCERTAIN EVENTS AND THEIR IMPACT $\ldots \ldots \ldots \ldots .4 .15$

5.0 RECOMMENDATIONS FOR FUtURE RESEARCH $\ldots \ldots \ldots \ldots \ldots \ldots \ldots \ldots \ldots \ldots \ldots$

5.1 ENERgY INVESTMENT BUILding SURVEY $\ldots \ldots \ldots \ldots \ldots \ldots \ldots \ldots \ldots \ldots . \ldots \ldots$

5.2 ATTITUDES OF THE NONRESIDENTIAL ENERGY INVESTMENT

DECISION MAKER ............................ 5.3

5.3 BATtELLE'S SCENARIO InPUTS TO CORPORATE STRATEGY ........ 5.4

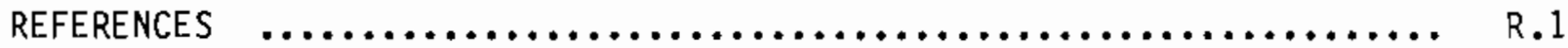




\section{FIGURES}

1.1 Factors Influencing the Nonresidential Energy Investment

Market ........................................ 1.2

3.1 Decision Participants Matrix $\ldots \ldots \ldots \ldots \ldots \ldots \ldots \ldots \ldots \ldots \ldots \ldots . \ldots \ldots$

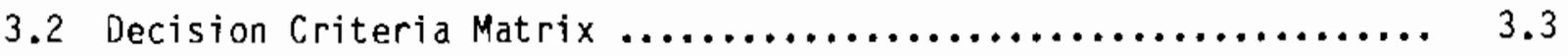

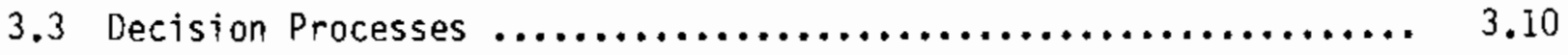

3.4 Decision Trajectory for the Low Risk Decision .............. 3.11

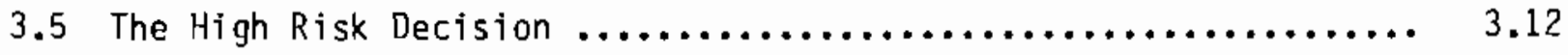

4.1 National Census Regions $\ldots \ldots \ldots \ldots \ldots \ldots \ldots \ldots \ldots \ldots \ldots \ldots \ldots \ldots \ldots . \ldots \ldots$

4.2 Net Migration $\ldots \ldots \ldots \ldots \ldots \ldots \ldots \ldots \ldots \ldots \ldots \ldots \ldots \ldots \ldots \ldots . \ldots \ldots \ldots$

4.3 National Weather Zones ................................. 4.10

\section{TABLES}

4.1 Net Migration Between Regions $\ldots \ldots \ldots \ldots \ldots \ldots \ldots \ldots \ldots \ldots \ldots \ldots . \ldots . \ldots . \ldots$

4.2 Shifting Industrial Sectors $\ldots \ldots \ldots \ldots \ldots \ldots \ldots \ldots \ldots \ldots \ldots \ldots \ldots . \ldots . \ldots . \ldots$

4.3 Total Square Footage in the Mercantile-Service Building Sector 1983 to 2006 

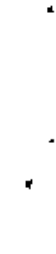


\subsection{INTRODUCTION}

The purpose of this report is to describe and to characterize the decision process in the nonresidential building sector as well as the variables infiuencing energy investment decisions, both of which impact the development of R\&D agendas for the 0ffice of Building and Community Systems (BCS). The report reviews the available information on the factors that influence energy investment decisions and identifies information gaps where additional research is needed. This report focuses on variables and combinations of these variables (descriptive states) that influence the non residential energy investment decision maker. Economic and demographic descriptors, energy investment decision maker characteristics, and variables affecting energy investments are identified. Figure 1.1 is a visual summary of the areas that influence the nonresidential energy investment market.

This report examines the physical characteristics of buildings, characteristics of the legal environment surrounding buildings, demographic factors, economic factors, and decision processes, all of which impact the nonresidential energy investment market. The emphasis of the report is on providing possible methodologies for projecting the future of the nonresidential energy investment market, as well as, collecting the data necessary for such projections. The use of alternate scenarios is suggested as a projection tool and suggestions for collecting the appropriate data are made in the recommendations.

Section 2.0 begins with a discussion of the physical characteristics of buildings which influence investment in energy efficient technologies. The physical descriptors mentioned in the report are

- building type (building activity)

- building size

- building age

- building location.

Each of these descriptors can be quantified and have an influence on what type of energy systems are used in them. 


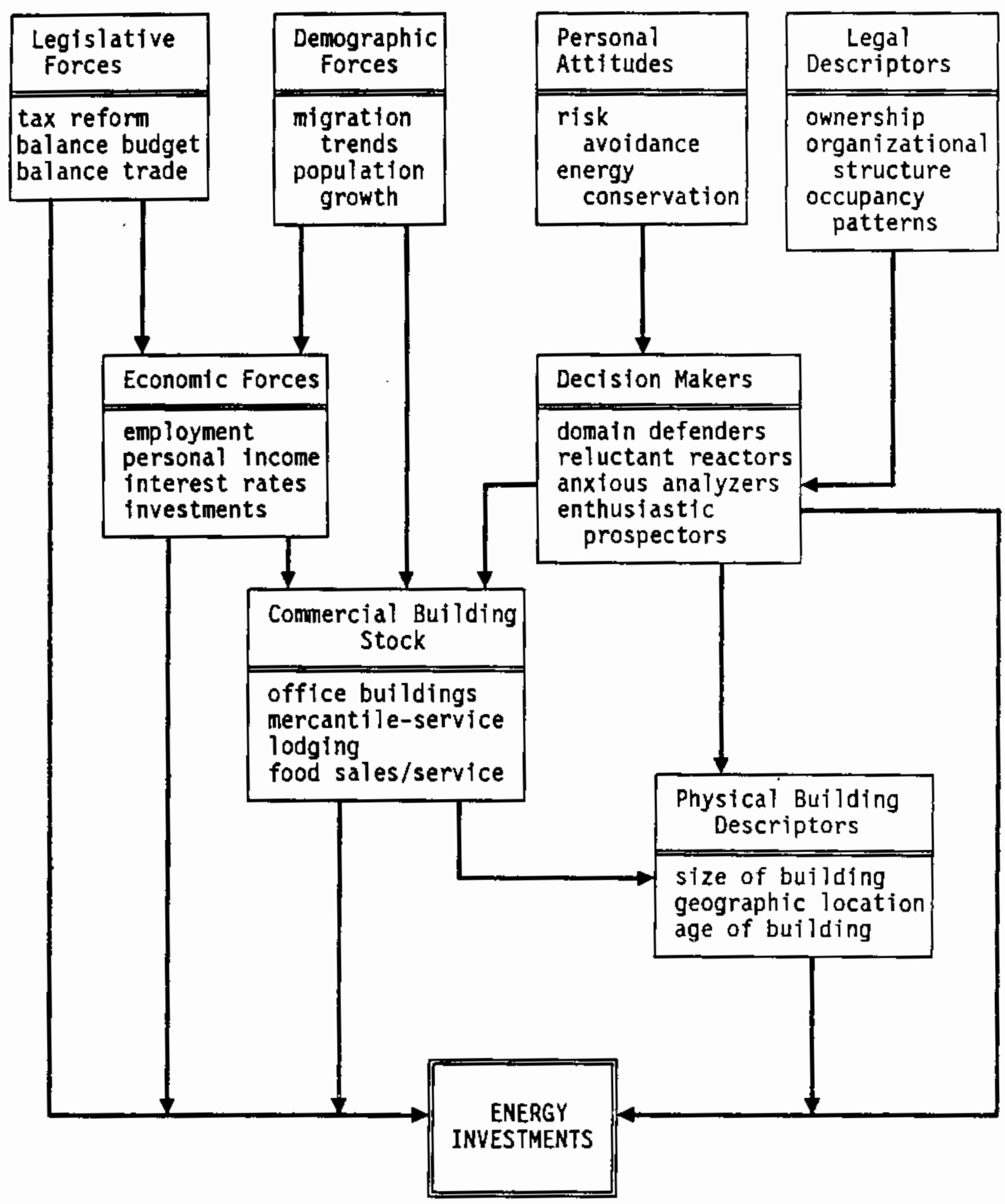

FIGURE 1.1. Factors Influencing the Nonresidential Energy Investment Market 
The physical descriptors are important but the legal factors involving the building tend to have more of a bearing on energy investment decisions. These legal descriptors influence the decision making process by defining who the decision makers are and in what type of environment the decisions are made. The legal descriptors discussed are

- types of ownership

- organizational structure of owner

- incentives for energy investment (tax incentives)

- occupancy patterns (resident owner or nonresident owner)

- occupancy status (leasing arrangements, vacancy rates, rental/lease market strength).

Section 2.2 puts the energy investment decision into perspective with the larger national picture. Demographic and economic influences are brought to light. The demographic descriptors discussed are

- age-specific population patterns

- regional population growth patterns

- population migration rates.

As a general rule, economic development and therefore building construction growth is high in areas of high population growth. Age-specific population growth influences the types of buildings constructed. Migration rates provide a clue to regions which have potential for economic investment and those that do not.

The strength of the energy investment market is also subject to the economic trends that influence all investments. The report discusses economic descriptors which can serve as a barometer for the nonresidential energy investment market. A brief overview of these descriptors includes

- personal income

- employment figures

- housing starts

- U.S. trade balance

- national debt and consumer credit 
- interests rates

- foreign investments

- number of new businesses

- value of new construction

- building vacancy rates.

Section 3.0 covers the organization decision processes and the individual decision maker attitudes which influence investing in energy efficient equipment. The organizational decision process is discussed in terms of decision process drivers.

- Building ownership

- Building use mode

- Construction-contract bid mode.

These process drivers influence who the decision makers are and the extent that they influence the energy investment decision.

The report points out that the decision process is not just affected by the physical and legal descriptors mentioned, but by the more intangible interactions of the decision makers and the individual perceptions and attitudes the decision makers have. The concept of the organizational "buying center" is discussed along with the characteristics of high and low risk decisions within an organizational environment. A number of variables are discussed which may influence the decision maker's propensity towards making high risk decisions. It is pointed out that this high risk individual is more likely to adopt new technologies, and be a "enthusiastic prospector" as opposed to a "domain defender."

Section 4.0 discusses the importance of research in the areas that influence the nonresidential energy investment market. This section reviews the available information and points out the lack of attitudinal data from available building surveys. This section also points out the value of information concerning the influences of energy investment decisions in projecting the state of the energy investment market. Research into the areas that influence the energy investment market will aid in tracking and projecting the strength of the energy investment market. 
There are a variety of methodologies available for projecting unknown outcomes once the areas of influence have been explored. The use of alternate scenarios is suggested. Alternate scenarios attempt to foresee unexpected changes in the areas of influence by making a number of likely projections based on possible changes in the areas of influence. To demonstrate the usefu?ness of scenario projections, an example scenario is constructed by proceeding through six steps.

- Defining and structuring the topic

- Identifying the areas of influence on the topic

- Specifying relevant descriptors of the areas of influence

- Building consistent trends and developments

- Introducing significant uncertain events

- Interpreting impacts and establishing forecasts. 



\subsection{DESCRIPTORS INFLUENCING THE ENERGY INVESTMENT MARKET}

This section discusses the physical descriptors, the legal descriptors, the demographic factors, and the economic trends that impact the nonresidential energy investment market. Descriptors, as they are used, in this report are variables that measure the areas of influence on energy investment decisions. For example, demographic and economic trends are two areas that influence the energy investment market. Some descriptors that would measure these areas of influence are regional migration rates, population growth rates, employment rates, and interest rates. Descriptors described in this section were gleaned from a synthesis of studies and literature reviews on energy investments in the nonresidential sector. Energy investments may involve new construction or the retrofitting of existing structures.

This section identifies descriptors of areas of influence that relate to energy investments. Specifically this section describes the physical, legal, demographic and economic descriptors influencing the nonresidential energy investment market. Many characteristics that follow relate directly to the energy investment decision process and are discussed in more detail in Section 3.0 .

\subsection{PHYSICAL DESCRIPTORS AFFECTING ENERGY INVESTMENTS}

Physical descriptors are those that deal with building characteristics and the location of the building. Physical descriptors include:

- building type (building activity)--offices, retail stores, grocery stores, schools, hospitals, lodging, restaurants, warehouses

- building size-square footage

- building age--year constructed, equipment life

- building Tocation--climate, geography.

Within the physical descriptors category, building type (activity in the building) and building size often provide clues to the potential for energy efficient investments. Refrigerated warehouses, grocery stores, and restaurants, for example, have high energy consumption levels per square foot. 
Educational facilities have low consumption levels. (Nieves and Fang 1985). Large energy costs attributable to building operation will naturaliy attract management's efforts for improved energy efficiency (OTA 1982; Temple, Barker, and SToane 1984; Feldman undated).

The region of location impacts the demands put on the heating, ventilation, and air conditioning (HVAC) systems and lighting systems in buildings. Local energy costs, the availability of energy efficient systems, zoning ordinances and building codes are all subject to the location of the building. These factors must be considered in making decisions concerning energy related investments.

The age of the building and its energy systems is an important consideration in determining whether or not to retrofit. Operating costs of outdated HVAC and 1 ighting systems are a cost burden worth reducing. In many building designs, where energy efficiency was not of concern, major investments can be cost prohibitive.

Data on the descriptors mentioned in this section are available from a couple of sources. The Nonresidential Building Energy Consumption Survey (NBECS), produced by the Energy Information Administration of the Department of Energy, is a comprehensive data source for the physical descriptors mentioned in this section. A second excellent source is the Dodge division of McGrawHi 11 Inc., which publishes the F. W. Dodge Reports and maintains building data bases.

\subsection{LEGAL DESCRIPTORS AFFECTING ENERGY INVESTMENTS}

Legal descriptors are those that define the function or shape the activity of the building. Legal descriptors include:

- types of ownership--jndividual, corporate, governmental units, partnerships, institutional investors

- organizational structure--independent stores, franchises

- occupancy patterns-resident owner, nonresident owner 
- occupancy status--vacant, length of lease, type of lease, number of tenants, strength of rental/lease market

- tax incentives for energy conservation investments.

In some cases, legal descriptors may influence energy investment decisions more than physical descriptors. Buildings owned by corporations tend to be larger than those owned by individuals, but most forms of ownership are found across a range of building types. Larger buildings have different energy requirements than smaller buildings. Corporations have a hierarchical decision process and usually are more informed on energy investment decisions, but smaller partnerships and individuals tend to have fewer information resources (Nieves and Fang 1985). The more informed organizations should know of the new energy technologies and be in a better position to make an informed decision about their energy system needs.

The organizational structure of the owners of a building affects energy investment decisions. Generally, for buildings that constitute a single business, investment decisions are centralized, residing with the owner. In the case of geographically dispersed chains and franchise stores, the local managers may have input to the centralized decision making process at the corporate level or may make the decision themselves (Dornbusch 1984).

Occupancy patterns are an important consideration in energy investment decisions, whether for new construction or the retrofitting of a building (George, da Silva, and McRae 1986). Resident owner patterns tend to encourage energy investments due to the acceptability of longer payback periods. Resident owners or investors are often insulated from energy costs by lease arrangements (OTA 1982).

The occupancy status, including types and lengths of leases, is another major consideration in energy investments and retrofitting. In the owner/ nonresident or developer/speculator situation, the marketability of the building or its lease can be a factor (George, da Silva, and McRae 1986). In a competitive building market, buildings that have energy efficient equipment are more marketable than others. Landlords will renovate outdated energy systems for potential long lease tenants. A lease market with short leases and high 
turnover hinders energy investments. Since landlords feel the payback period should never be longer than the duration of the lease (George, da Silva, and MCRae 1986).

Tax incentives for energy investment, zoning ordinances, and building codes affect the energy investment decision. Zoning ordinances and building codes shape initial design efforts. Tax incentives are not the primary motivation for building or renovating, but owners usually take advantage of them (George, da Silva and McRae 1986).

\subsection{DEMOGRAPHIC DESCRIPTORS}

Economic and demographic trends affect the number, type, and location of building starts and renovations. Examining the relationship between these descriptors and the building stock allows varying projections of the building stock, depending on the value of these descriptors. Projection of the building stock aids the identification of future energy investment decision makers and the extent of their influence.

The demographic descriptors of importance are age-specific population increases, regional population growth patterns, and migration rates. Construction activity follows population growth and shifts. Age-specific population growth creates the demand for certain types of construction. For example, a region's population which has an increasing percentage of people over 60 may require increases in health care facilities for the aging population. An increasingly younger population in a region creates the demand for additional education facilities. These increases also affect regional housing starts, which, in turn, affect the nonresidential building market (Construction Review March/Apri 1, 1983). Monitoring population changes can indicate the regions where construction activity will increase. Increased construction activity means the potential for extensive energy investments in the region.

Population data is readily available from government sources. The U.S. Bureau of the Census produces statistics on regional population and agespecific populations. The Office of Business Economics (OBERS) model is a historical population projection model used by the Census Bureau. Varying levels of fertility, mortality, and net migration rates are used to project 
low, middle, and high population figures. A major problem with these projections is use of the net migration rates, since they are estimated on the previous ten year census period. For example, the population projections for 1980 to 2000 are based on the 1970 to 1980 migration patterns. With this methodology, areas of high net migration are shown to receive immigrants (whether they actually will or not) through the year 2000. The model does not incorporate fluctuations in migration trends within the decade.

Income tax return data from the Internal Revenue Service (IRS) provide a methodology to determine annual migration trends. Since approximately $90 \%$ of the population is represented by income tax returns, analyzing the annual migration trends with IRS data creates a better projection of regional populations from which better scenarios can be produced (Rogerson and Plane 1985).

\subsection{ECONOMIC DESCRIPTORS}

Besides demographic trends, a number of economic descriptors can aid in the tracking of regions with a potential for extensive energy investments:

- personal income--Increases in personal income create the demand for new retail businesses, create manufacturing needs, and boost the overall economy. A healthy economy promotes construction activity and the potential for energy investments.

- employment figures--Employment figures for the construction industry give an indication of building activity. Employment figures by occupational categories influence the types of buildings that will be constructed. For example, white collar employment creates the demand for additional office and service industry space.

- housing starts--Increases in housing starts create the need for associated retail establishments (shopping malls, convenience stores).

- U.S. trade balance-U.S. world competiveness affects the growth of manufacturing facilities and warehouses for storage of inventories and imports.

- national debt and consumer credit--These decrease building construction by "crowding out" investment monies. 
- interests rates--Corporate bonds, corporate and residential mortgage rates affect building and housing starts.

- foreign investments--Increasing foreign investments are an additional money source for expansion and construction.

- number of new businesses--Rusiness expansion increases the energy investment market.

- value of new construction--Annual values of new construction are a measure of building construction growth.

- building vacancy rates-These rates indicate the strength of the building rental market. As already discussed, energy investments are influenced by the demand for building space.

Each economic descriptor measures some aspect of the economy related to the building market. Descriptors are sensitive to changes in the areas of influence (For example, legislative action could be taken to reduce the trade imbalance. This would appear in the trade balance numbers.) Monitoring these economic descriptors and demographic descriptors gives an idea of the potential for, and the locations of, future energy investmert opportunities.

Economic data is readily available from government sources. The U.S. Department of Commerce publishes a number of data sources, Survey of Current Business and Construction Review to name two. 


\subsection{DESCRIPTORS OF ENERGY INVESTMENT DECISION MAKERS}

This chapter focuses on the decisionmakers and the decision process. The preceding variables affect the energy investment decision maker and the extent of his energy investments, as they are important components in deciding on new construction and retrofits. Although owners may be the major decision makers, there are other people involved in these decisions in the designing and construction industries (architects, engineers, contractors, manufacturers). The number, size, and type of buildings under the control of these decision makers is difficult to ascertain. Detailed quantitative information on ownership patterns (corporations, partnerships, individuals) by building type or by square footage is not available (Nieves and Fang 1985). Such information is valuable in determining the future size of the energy investment market in the nonresidential building sector.

Staff at the Pacific Northwest Laboratory (PNL) have identified the important decision makers and decision criteria in the construction of nonresidential buildings (Watts, Johnson, Smith, and Westergard 1985). The PNL decision matrix was developed for the decisions involving the construction of new buildings; however, it also provides an insight into retrofit decisions. Understanding the decision process and the variables influencing the process imp roves market penetration.

A convenient way to display and summarize the interaction of decision makers mentioned above is the decision matrix prepared by PNL staff (Watts, Johnson, Smith, and Westergard 1985). The completed matrix depends on the three decision process drivers: ownership, occupancy, and contracting media. Two examples of completed matrices are in Figures 3.1 and 3.2. Figure 3.1 represents the influence and times of influence for particular decision makers. Figure 3.2 represents the amount of influence particular decision criteria have. The vertical axis of the matrix lists the building phases from predesign through building occupancy. The horizontal axis is a time line that represents the timing and duration of each phase. for Figure 3.2, the horizontal axis lists the categories of decision criterion. The degree of shading in each 
Research Utilization Project Energy Decisions

and

Decision Participants

in the Building Process

Ownerahip/Residence: Corporation of Profeasionalg/Aesident Building Occupaney Type: Small Ottice Bldg/Businoss Rosidence

Conerruction Mode: Design-Bid-Build

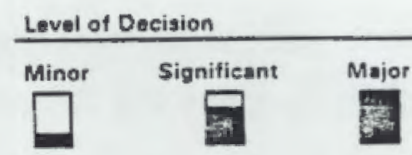

\begin{tabular}{|c|c|c|c|c|c|}
\hline \multicolumn{6}{|c|}{ DECISION PARTICIPANTS } \\
\hline $\begin{array}{l}\text { Own/ } \\
\text { Finance }\end{array}$ & \begin{tabular}{|l|} 
Plen/Design/ \\
Specity/Admn
\end{tabular} & \begin{tabular}{|l|}
$\begin{array}{l}\text { Sup } \\
\text { piy }\end{array}$ \\
\end{tabular} & $\begin{array}{l}\text { Construetion } \\
\text { Contract }\end{array}$ & \begin{tabular}{|l|}
$\begin{array}{l}\text { Reg- } \\
\text { late }\end{array}$ \\
\end{tabular} & Uso \\
\hline 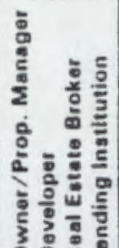 & 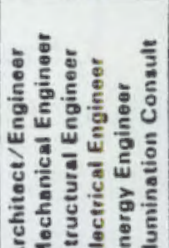 & 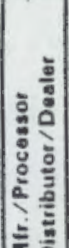 & 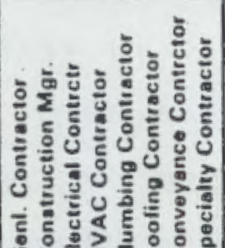 & 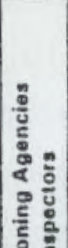 & 9 \\
\hline
\end{tabular}

DECISION SPACE

ENERGY DECISION EVENTS/DESCRIPTION

RRE.DESIGN ACTIVIIES

Building Program

Financing

SCMEMATIC DESIGN

External Appearance

Building Loyoure

DESIGN DEVELOPMENT

Internal Apposarsencs

Illumination Lovel/Lighting Efficiency

Energy Sources Selection: Fuol Typers)

HVAC Systoms/Integration

Plumbing Systeme

Electrical System

Conveyances

Sheli/Envelope

R/U Velues: Individual/Combined: - All Systems

BID PROCESS

Budgat. Bid Pkgs/Eval. Proposals/Select Contractors Negotiate Substitutn/Modify Specs/Final Contrets

BUILPING CONSTRUCTION

Structural installation Methods

HVAC, Plumbing, Eloctrica! Systems Tochniques HVAC Baiancing

Substitutn: Unavailab./Ineffective Component/Spec Structural/System Partormance Verification (Q.A.) Conveyence Instalietion \& Operation

Inspection/Compliance: Modification to Comply

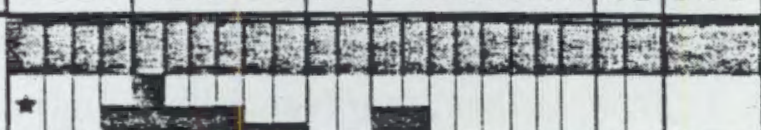

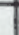

का.

$\star$

(1) 要运

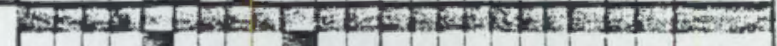

t

ता 110

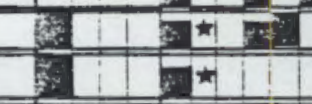

$+$

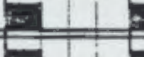

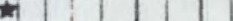

.

$\frac{11}{5+1}$

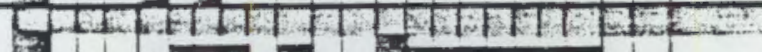

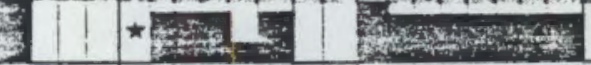

*

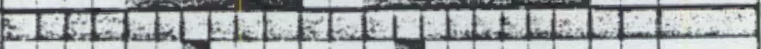

115

$\rightarrow$ ing

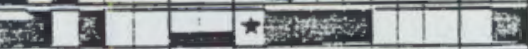

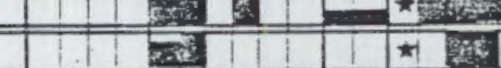

$112 y$

(1)

+5 :

$2+11 \div$

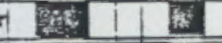

(2)

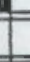

(1)

BUILOING OCCUPANCY

Inspection/Testing/Acceptence by Owner

Operations \& Maintenance Procedures

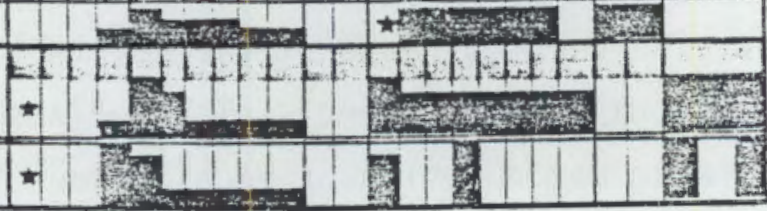

FIGURE 3.1. Decision Participants Matrix (Watts, et al. 1985, p. 2.27.) 


\section{Research Utilization Project Energy Decisions \\ and \\ Decision Criteria \\ in the Building Process}

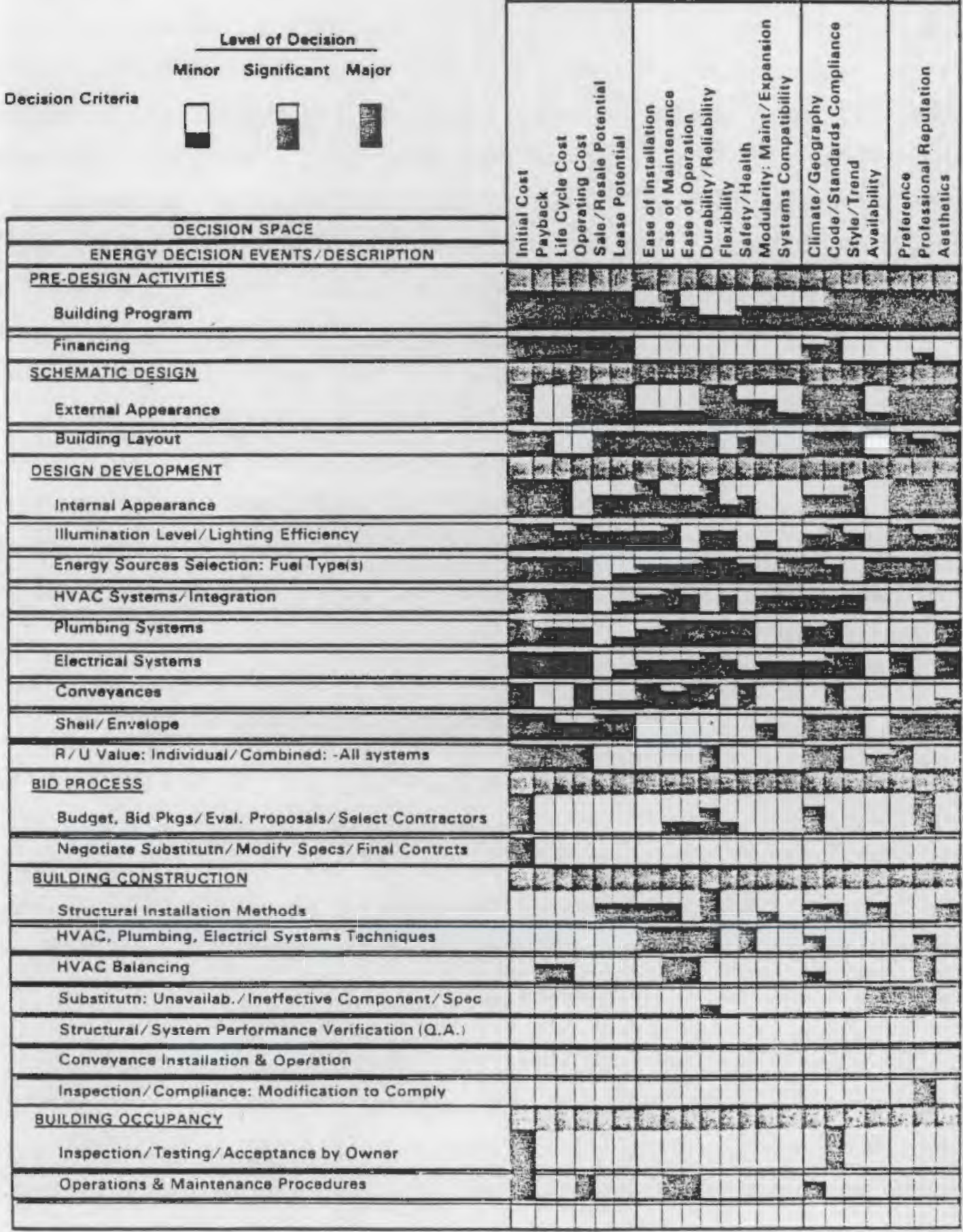

FIGURE 3.2. Decision Criteria Matrix (Watts, et al. 1985, p. 2.28.)
Ownership/Rezidence: Resident

Smail Office Bldg/Bus Residence

Building Occupancy Type:

Conatruction Mode: Design-Bid-Build

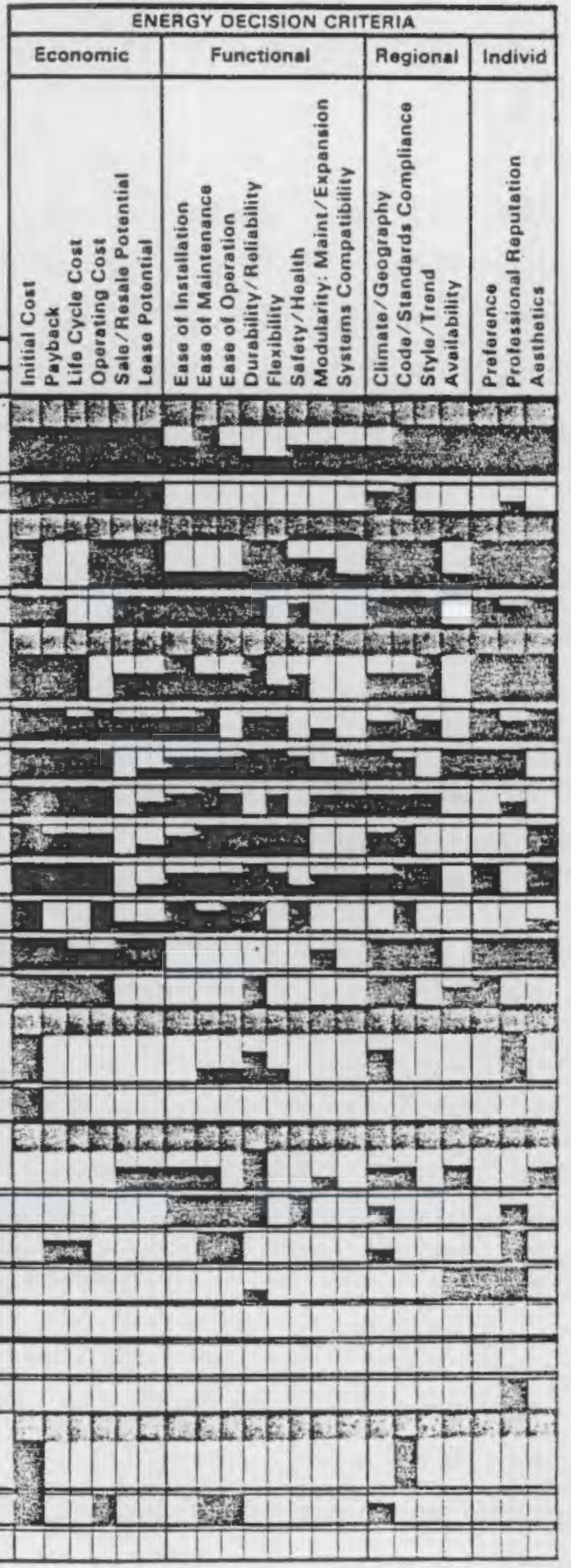


square is the amount of influence that the decision maker or criteria has over the building construction during that particular building phase (Watts et al., 1985).

The decision makers' influences and times of influence depend on the process drivers and may vary from situation to situation. Generally, owners are the strongest potential influence over decisions affecting energy related investments. The financial supporters base their decisions on the marketability of the structure if foreclosure becomes necessary. The type of ownership affects the number of decision makers and their amount of influence. In the predesign and schematic phases of construction, the architects and engineers become important decision makers. Architects and engineers are concerned with the practicality and aesthetics of the energy technology. In the case of large corporations, they may be in house staff or they may be from architectural and design firms. Availability of materials must be considered in the design phase and manufacturers and suppliers have their opportunity for input. In the construction phase, the contractors and subcontractors may operate as decision makers and consultants in possible design changes. Finally, the inspectors of building codes and the future occupants may request changes affecting energy conservation measures.

\subsection{DECISION PROCESS DRIVERS AND INVESTMENT DECISION CRITERIA}

Decision opportunities appear to follow patterns that vary with building ownership/occupancy, use of building, and the construction contract mode (Watts, et al. 1985). These variables are defined as decision process drivers. Energy investment decisions vary as the decision process drivers change. Three important process drivers are building ownership/occupancy, building use mode, and construction contract bid mode.

\subsubsection{Building Ownership/Occupancy}

Building ownership and occupancy patterns were discussed in Section 2.1.1. Who owns a building, whether corporation, partnership, or individual, determines the number of decision makers and the investment decision process. Knowing whether or not the owner will occupy the building provides clues to 
identify the major decision makers and how decisions are made. The owners' occupancy patterns can be classified into four categories:

1. resident owner--expects to occupy the structure after it is completed, therefore they will be more concerned with energy and operational costs

2. nonresident owner--expects to lease the building and may or may not have the responsibility of operation and maintenance, including utility bills

3. developer/speculator--expects to sell the structure to future landlords or resident owners, therefore will not be paying for the operational costs

4. corporate franchise owner--expects to occupy the premises but design and investment decisions are made at corporate headquarters, not locally.

Each of these ownership modes can involve many types of decision makers and a variety of different decision criteria and processes. These occupancy patterns can be filled by partnerships, corporations, governmental bodies, institutional investors, and nonprofit organizations. The organizational structure of the owning entity affects the energy investment decision. In the case of franchises or chains, energy investment decisions may be made locally, away from the centralized decision process of the headquarters.

\subsubsection{Building Use Mode}

Building occupancy/use mode, the second decision process driver, can be categorized into three broad groups:

1. residential--single-family, multifamily low rise, and multifamily bigh rise

2. commercial--small office, light commercial, large office, recreational facilities, warehouse, retail stores, other nonindustrial buildings

3. institutional--government, religious and charitable organizations, hospitals and nursing homes. 
Commercial and institutional buildings are usually more expensive to construct and require different energy systems than residential buildings. Institutional buildings, particularly hospitals, may require more sophisticated HVAC systems, where as, retail stores usually require a greater lighting capacity. For the purpose of this report, the commercial and institutional modes are the nonresidential buildings of concern.

\subsubsection{Construction-Cont ract Bid Mode}

This process driver tends to influence who has control over the decisions of what energy systems to use. For example, with the negotiated construction contract mode, various parts of the building task are contracted out to reputable contractors. These contractors, while following the wants of the owners to some degree, have control over their part of the construction process. The owner's influence in the energy investment decision lessens as you move down the list below. The Construction-contract bid mode, the last decision process driver to be considered, falls into four groups:

1. design, bid, build--The design activities are initially set forth, a bid process is followed, and then the building is constructed by the successful bidder.

2. design, build--This process eliminates a separate bid process, the owner is usually further removed from the key energy conservation decisions because the contract includes both design and the construction tasks.

3. negotiated construction contract--In this process various parts of construction are let to individual contractors on the basis of past experience or reputation without accepting and reviewing multiple bids.

4. fast-tracked and multiple bid package jobs--This process involves using pre-engineered, prefabricated units, and energy systems; it is possible that pre-engineered systems, such as in a metal building, are designed and built with no knowledge of what mechanical systems are to be employed after the purchase and erection of the shell. 


\subsubsection{Energy Investment Decision Criteria}

The importance of any one investment decision criteria is a function of the decision process drivers. In the case where the owner will occupy the structure, the operational costs and equipment life may be very important. If the owner intends on leasing or selling the structure, the importance of these criteria may be diminished. The ownership mode impacts the emphasis given to operating costs and equipment life.

Monetary investments in energy systems are considered carefully. Energy systems must have an acceptable initial cost versus payback period. The life cycle and cost of operation must be considered. The marketability of the structure can be affected by its energy use systems. Energy investments should enhance resale and lease potentials.

Other criteria affecting energy decisions are the ease of installing the energy system, maintenance of the system, region of location, and the individual decision makers. Equipment must be appropriate for the region's climate and building codes. Some equipment may not be available in certain regions. Decision makers also are affected by individual preferences, a need to maintain their professional reputation, aesthetics, and their risk avoidance attitudes.

Knowledge of the variables influencing energy investments, including those affecting the decision makers, is a tool by which projections and scenarios of the energy investment market can be developed.

\subsection{ENERGY INVESTMENT DECISION MAKERS: ATTITUDES AND THE DECISION PROCESS}

Decision opportunities follow patterns that vary with the decision process drivers. These drivers indicate which decision makers are called on for energy conservation investment decisions. The energy investment decisions involve a number of people in six broad areas:

1. owners/financiers--owner/property manager, developer, real estate broker, lending institution

2. designers/specifiers--architect, mechanical engineer, structural engineer, electrical engineer, lighting consultant 
3. manufacturers/suppliers--manufacturer/processor, distributor/dealer

4. contractors--general contractor, construction/project manager, electrical contractor, HVAC contractor, plumbing contractor, roofing contractor, conveyance contractor, specialty contractor (including all other subcontractor participants)

5. regulators--zoning agency, inspectors

6. building users--occupant/lessee, energy manager, building/maintenance manager.

These people have different viewpoints about the most efficient and least expensive energy systems to use in construction. The various categories of decision makers use their influences in varying stages of construction.

\subsubsection{The Decision Process}

The decision makers and the degree of their influence in energy conservation decisions varies by ownership, building use, and construction contract mode. The decision process becomes more complex as the interaction between various decision makers in an organization is examined. Corporate decisions can go through several levels of management. A comprehensive literature review conducted at the Oak Ridge National Laboratory, (Dinan 1986), identifies a dynamic "buying center" that exists in organizational purchase decisions (for our purpose, retrofitting and building construction). The "buying center" is a cross departmental decision group. The composition of the buying center depends on the impact that the proposed product will have on different functional areas in the buying organization (Hutt 1981). If retrofit equipment is purchased, the top management, the purchasing department, and the engineers will have input into the decision. In the construction of a new building, the buying center of interest for energy investments would be the top management, architects, engineers, and the resedrch department.

Although the membership of the group may change, the roles remain fairly constant. The gatekeepers within the group control the flow of information among group members. The influencers supply information used to the evaluate alternatives or to set specifications (e.g., an engineering consultant or 
architect). The deciders are the actual decision makers. They may not have the formal authority to make decisions but have the influential power to sway the formal buyers.

Although group social forces are important in the decision process, individuals make the decisions. They bring with them varying perceptions and belief systems that ultimately sway their decisions. The idea of the buying center may be key in predicting who the decision makers are, but knowledge of the actual individual decision maker cannot be replaced.

\subsubsection{Attitudes of Decision Makers}

Four major factors contribute to the power of the individual in the buying center: 1) his level of technical competence and credibility; 2) the amount of information he controls; 3 ) support from his top management; 4) his reputation as an authority in the specific area of concern.

Two decision makers, occupying the same position in the buying center and equal in their levels of influence, will not always make the same decision. The individual characteristics of the decision maker are important, especially those that affect his attitudes. Dinan (1986), identifies a number of variables which may influence organizational decision maker attitudes.

- involvement with organization activities

- educational background

- age

- social origins

- years of work/job tenure

- career satisfaction

- ideology.

The willingness to take risks is an atiilinds wich may be shaped by these variables. A review of the literature concerning risk taking identifies central characteristics:

- The risk-taker is a person who needs stimulation and seeks change, novelty and adventure.

- The risk-taker is characterized by high activity level, energy and dynami sm. 
- The risk-taker often has difficulty in restraining his drives and is prone to act on impulse.

- The risk-taker tends to exhibit a high degree of independence in his thinking and actions.

- The risk-taker struggles against norms or rules that impinge on his personal freedom.

- The risk-taker tends to refrain from long-term planning. He prefers to act according to the prevailing situational demands without the 1 imitations of previous commitments and undertakings. (Keinan and Gome-Nemi rovsky 1984.)

Risk avoidance is another major motivation in decision making in the nonresidential sector.

". - fear is one of the major influences in industrial buying. Fear of displeasing the boss. Fear of making a wrong decision . . . fear of losing status. Fear indeed, in extreme cases, of losing one's job." (Lazo 1960, p. 265.).

The decision process has two major dimensions, beliefs about cause/effect relationships and preferences regarding possible outcomes (see Figure 3.3 ). The amount of certainty or uncertainty along these two dimensions affects the ease and quality of decision making (Hall 1982). In clear-cut situations, such as reordering specific inventories, the decision process involves computational strategy. These are low risk decisions. As the frequency of the low risk

Preferences regarding possible outcomes

\begin{tabular}{lll|l|}
\multicolumn{1}{c}{} & \multicolumn{1}{c}{ CERTAINTY } & \multicolumn{1}{c}{ UNCERTAINTY } \\
\cline { 3 - 4 } & CERTAIN & Computational & compromise \\
\cline { 3 - 4 } $\begin{array}{l}\text { Beliefs about } \\
\text { cause/effect } \\
\text { relations }\end{array}$ & UNCERTAIN & judgmental & inspirational \\
\cline { 3 - 4 } & &
\end{tabular}

FIGURE 3.3. Decision Processes (Hall 1982, p. 178) 
decision increases, the decision process becomes more routine and is often delegated to lower levels in the organization. The process involves little or no discussion among managers, and all the information needed for the decision is known (see Figure 3.4). When outcome preferences are clear, but cause/ effect relationships are uncertain, we will refer to a judgmental strategy for decision making. Where the situation is reversed and there is certainty regarding cause/effect but uncertainty regarding outcome preferences, the issue can be regarded as calling for a compromise strategy for decision making. Finally, where there is uncertainty on both dimensions, we will speak of the inspirational strategy for decision making, if indeed any decision is made (Thompson 1967).

It is the uncertain areas of compromise, judgment, and inspiration that encompass the realm of the high risk decision. As Figure 3.5 diagrams, as the amount of risk increases, the level of discussions and information searches increases. Coalitions among the "buying center" are formed. Internal and external expertise is usually consulted in an effort to obtain information. The decision process can be prolonged as the information search continues. After discussions and information searching, the coalitions in the buying

\section{The Low Risk Decision}

Decision - issue $\quad$ Process characteristics $\quad$ Outcomes

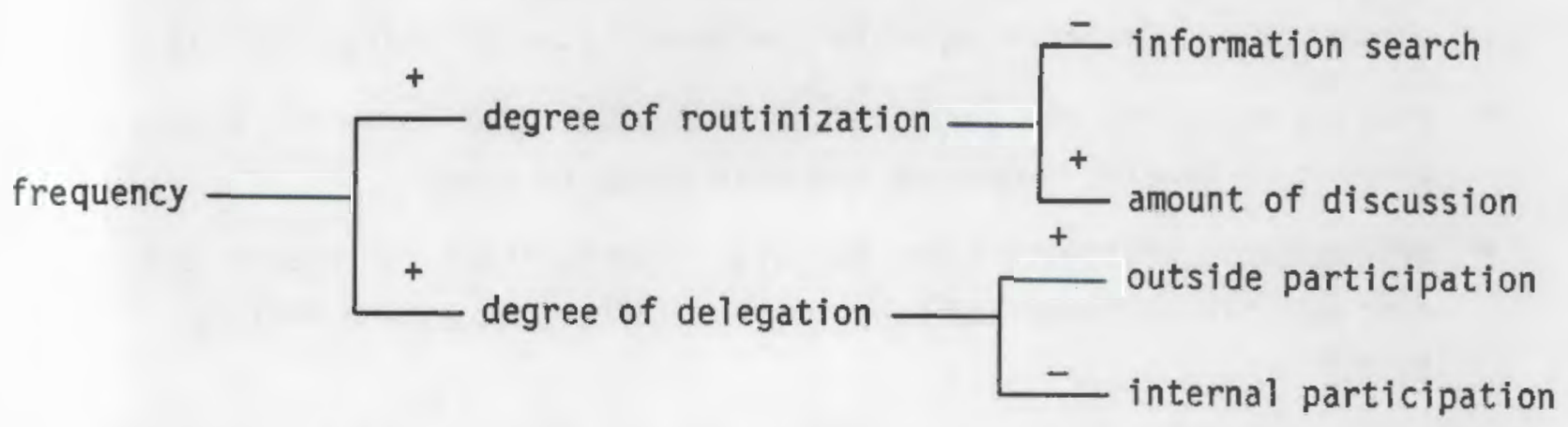

FIGURE 3.4. Decision Trajectory for the Low Risk Decision (Hall 1982, p. 177) 


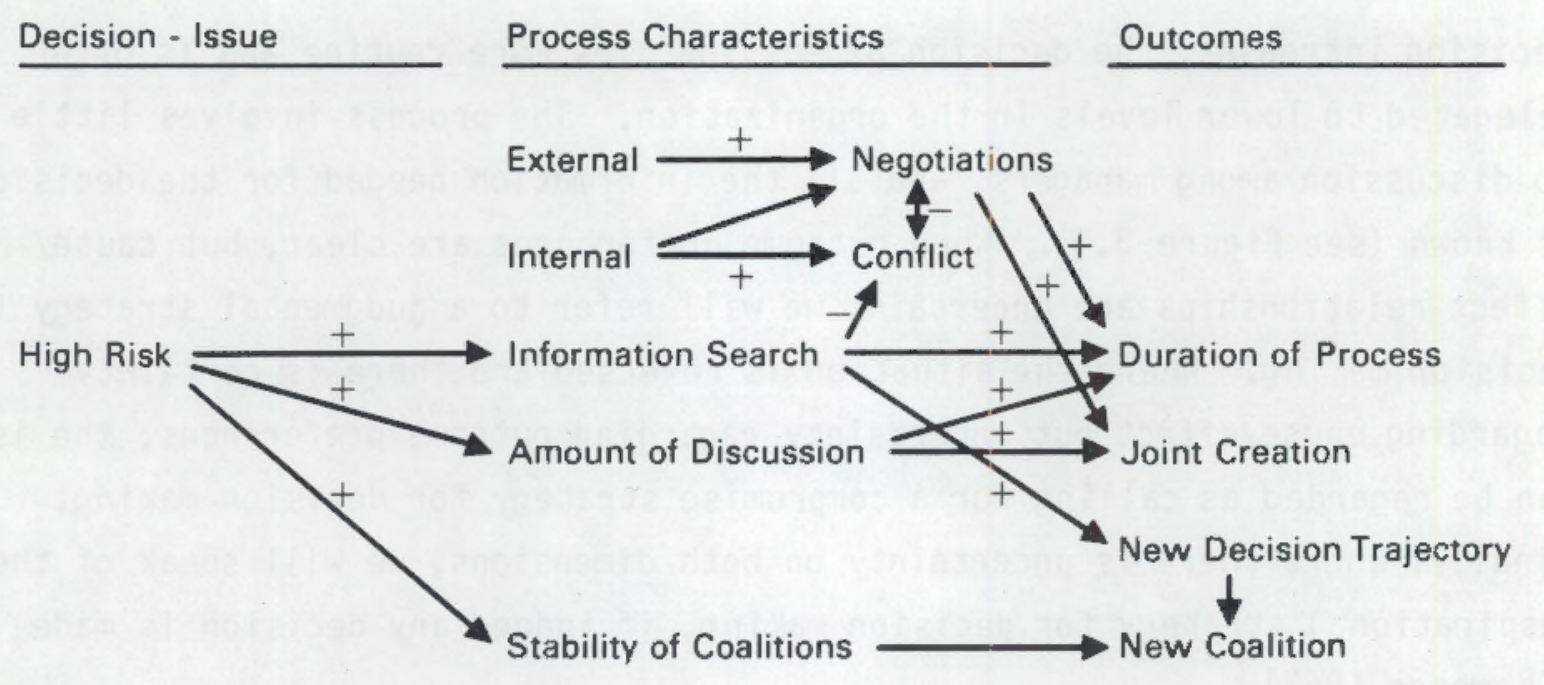

FIGURE 3.5. The High Risk Decision (Hall 1982, p. 177)

center can reach a joint decision or bring up new decisions to be made, starting the process over. New coalitions may form with the developing of a decision.

It is in the high risk decision with its complexity that individual attitudes towards risk taking come into play. In this sense the decision makers can be classified as:

- domain defenders who allow little change

- reluctant reactors who simply react to pressures. For example, an executive may be forced to adopt new technology in order to remain competitive. Change interrupts the normal flow of things for him.

- anxious analyzers who perceive change but wait for competing organizations to develop responses and then adapt to them

- enthusiastic prospectors who perceive opportunities for change and want to create change and experiment. (Miles, Snow, and Pfeffer 1974.)

Although group forces do contribute to decisions, it is the individual personalities that shape attitudes towards risk-taking. Varying levels of self confidence, self-esteem, anxiety, and risk style (the extent to which an individual overlooks or focuses on differences in stimuli) are personality 
variables affecting one's attitudes towards risk-taking. It is the high risk decision maker who would be more willing to accept new technologies. 



\subsection{MAKING PROJECTIONS OF THE NONRESIDENTIAL ENERGY INVESTMENT MARKET}

Information concerning these influences of energy investment decisions is important in projecting the state of the energy investment market. Research into the areas that influence the energy investment market will aid in tracking and projecting the strength of the energy investment market. There are a variety of methodologies available for projecting unknown outcomes once the areas of influence have been explored. Straight line, historical projections making use of detailed econometric and statistical models are scientific in their applications but cannot foresee the unexpected. Alternate scenarios attempt to foresee unexpected changes in the areas of influence by making a number of likely projections based on possible changes in the areas of influence. The following sub-sections are an exercise in scenario development. By examining the mercantile services building sector, the factors that influence the building industry, the types of building ownership, and the motivations of decision makers, the scenario example demonstrates the usefulness of scenarios in energy investment research.

The scenario is a combination of likely and unlikely happenings that will significantly impact the energy investment decision maker. The discussion is intended as an example of scenario development, not a rigorous, statistical model. First, the demographic stage is set through the year 2000; then, the anticipated legislative atmosphere is discussed. The scenario continues to build as economic and climatic descriptors are discussed. The mercantile service building stock is examined in light of the relevant descriptors and the decision makers are identified. Finally, uncertain significant events are introduced into the scenario and their impacts are discussed. The projections are based on a review of building surveys, government publications, and other relevant literature.

Available data from building surveys, government publications, and literature reviews were used to construct the example. The scenario development will proceed through six steps: 1) defining and structuring the topic; 2) identifying the areas of influence on the topic; 3) specifying relevant descriptors for 
the areas of influence; 4) building consistent trends and developments;

5) introducing significant uncertain events; and 6) interpreting impacts and establishing forecasts.

\subsection{DEFINITION OF TOPIC}

The energy investment decision makers in the mercantile service sector at the turn of the 21 st century provide the topic of the example scenario. For the purpose of this scenario, the United States is divided into the four national census regions: Northeast, North Central, West, and South (see Figure 4.1). The mercantile service building sector is defined as those buildings housing sales and displays of goods or services (excluding food). Included are:

- shopping malls

- strip shopping centers

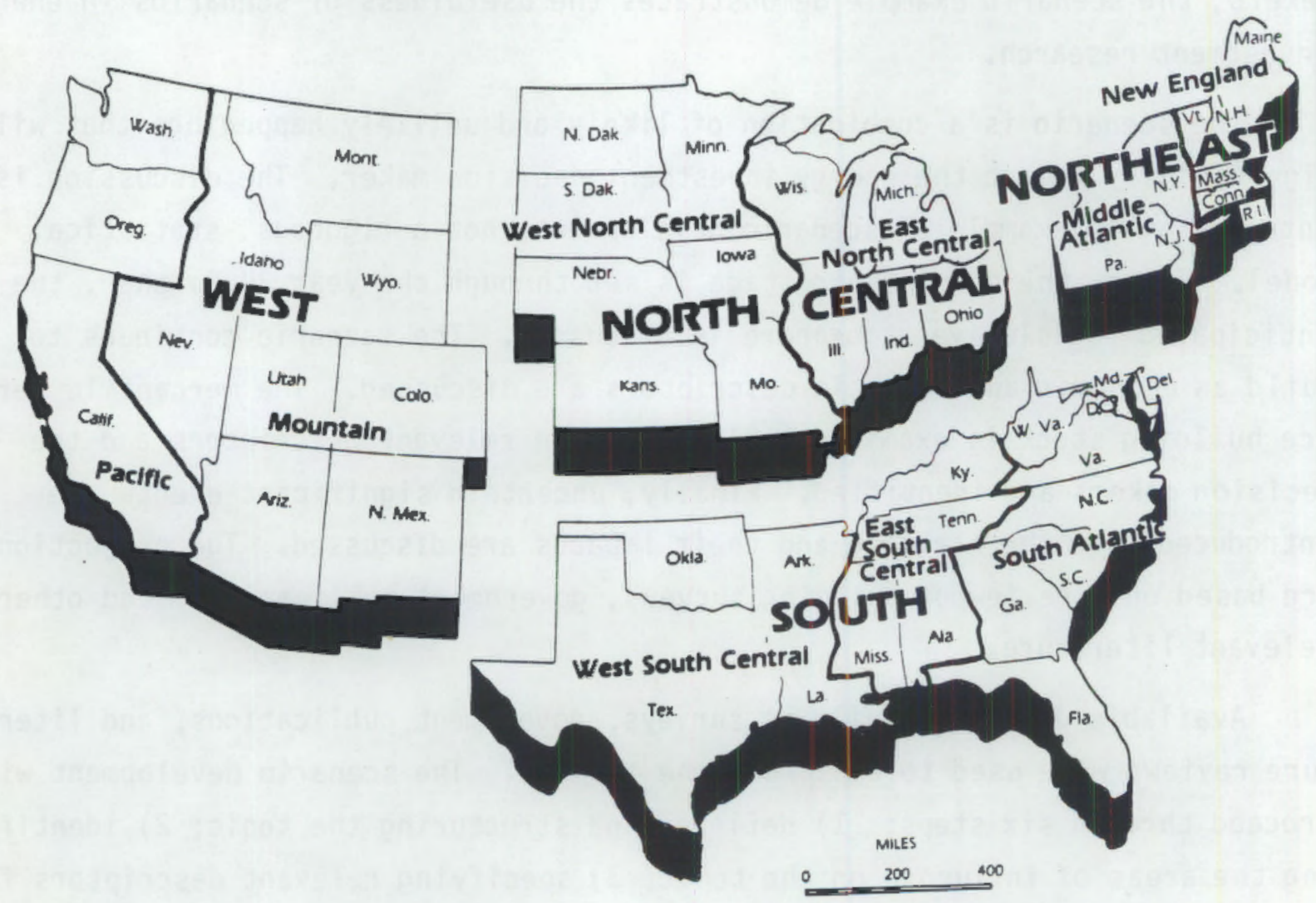

FIGURE 4.1. National Census Regions 
- single establishment retail sales--building materials, hardware, garden supply stores, department stores, apparel stores, furniture, home furnishings, equipment stores, drugstores, multi-retail establis hments

- wholesale goods (except food)

- services (except food)--laundry/dry cleaner, car wash, post office personal service, multi-service establishment

- automotive sales and service buildings--gas stations, automobile dealers, motor vehicle repair/service (EIA 1985).

A major variable affecting the market is building ownership. For the purpose of the example, the categories of ownership are corporate, individual, and partnership (Nieves and Fang 1985).

\subsection{IDENTIFICATION OF THE AREAS OF INFLUENCE}

Economic trends, demographic trends, legislative action, and climate influence energy investment decisions in the mercantile service building sector. The strength of the economy and the investment atmosphere affect the amount of business investments in new structures and retrofits of old structures. The types and number of buildings constructed are also influenced by the economy and investment atmosphere. These areas of influence define the bounds of possible energy investments for the decision maker. Within these bounds, the decision process shapes energy investments.

\subsubsection{Population Trends Examined}

Examination of population movements and growth patterns is a major tool in determining the condition of the energy investment market of the four national regions. Economic productivity, new construction, and energy investment possibilities in retrofits tend to be in areas of high population growth.

Migration patterns and population growth have changed in the 1970 's and 1980 's. The most densely populated regions of the United States were traditionally the Northeast and North Central. However, over the past two decades an increasing number of people have chosen to live in the West and the South (see Figure 4.2). Although migration to the west has slowed and there is 


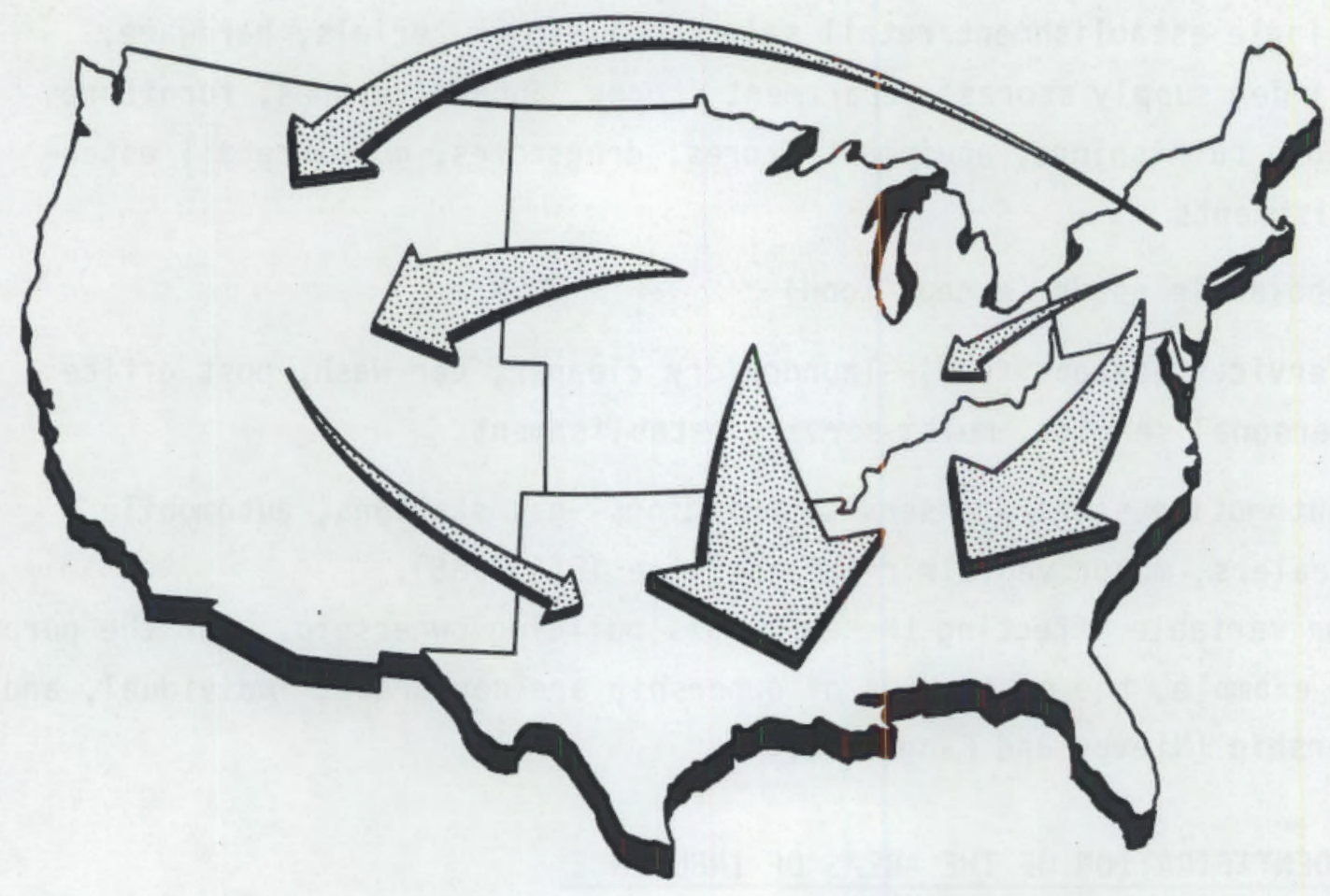

FIGURE 4.2. Net Migration

evidence of returning migration to the Northeast, demographers see the growth in the South and West continuing through the year 2000 (Kasarda, Irwin, and Hughes 1986).

The Northeast is projected to grow by only $2.8 \%$, from $49,581,000$ in 1985 to $51,000,000$ people in 2000. The slight increase will be due to a natural increase and probably not migration. The Northeast has been losing migrants to the other regions since the 1960's (Kasarda, Irwin, and Hughes 1986). Some evidence indicates that the out migration from the Northeast is reversing itself but not in large numbers (Rogerson and Plane 1985).

The North Central region (Midwest) has suffered the same fate as the Northeast. This region has lost migrants to the West and the South and gained a small amount from the Northeast. Its population is projected to grow by $5.9 \%$ from 59,662,000 in 1985 to $63,210,000$ in 2000. Even though the North Central 
is growing at a faster rate than the Northeast, the indication is that the North Central is continuing to decline while some migration is returning to the Northeast.

Table 4.1 shows that the West and the South are the fastest growing regions, and this trend is projected to continue. The West is projected to grow the fastest, 21.2\% from 1985 to 2000, but the South will add more people, approximately $13,000,000$. The West gained population from the other three

TABLE 4.1. Net Migration Between Regions (Kasarda, et a1. 1986)

\begin{tabular}{|c|c|c|c|c|c|}
\hline \multicolumn{6}{|c|}{ thouca } \\
\hline & $1955-60$ & $1965-70$ & $1970-75$ & $1975-80$ & $1980-85$ \\
\hline \multicolumn{6}{|c|}{$\begin{array}{l}\text { SOUTH } \\
\text { net exchange with }\end{array}$} \\
\hline $\begin{array}{l}\text { Northeast } \\
\text { Midwest } \\
\text { West } \\
\text { Total }\end{array}$ & $\begin{array}{r}+314 \\
+122 \\
-380 \\
+56\end{array}$ & $\begin{array}{r}+438 \\
+275 \\
-56 \\
+657\end{array}$ & $\begin{array}{r}+964 \\
+790 \\
+75 \\
+1,829\end{array}$ & $\begin{array}{r}+945 \\
+813 \\
+176 \\
+1,935\end{array}$ & $\begin{array}{r}+737 \\
+1,100 \\
+60 \\
+1,897\end{array}$ \\
\hline \multicolumn{6}{|c|}{$\begin{array}{l}\text { WEST } \\
\text { net exchange with }\end{array}$} \\
\hline $\begin{array}{l}\text { Northeast } \\
\text { Midwest } \\
\text { South } \\
\text { Total }\end{array}$ & $\begin{array}{r}+285 \\
+760 \\
+380 \\
+1,425\end{array}$ & $\begin{array}{r}+224 \\
+415 \\
+56 \\
+695\end{array}$ & $\begin{array}{r}+311 \\
+472 \\
-75 \\
+708\end{array}$ & $\begin{array}{l}+518 \\
+634 \\
-176 \\
+976\end{array}$ & $\begin{array}{r}+234 \\
+475 \\
-60 \\
+649\end{array}$ \\
\hline \multicolumn{6}{|c|}{$\begin{array}{l}\text { MIDWEST } \\
\text { net exchange with }\end{array}$} \\
\hline $\begin{array}{l}\text { Northeast } \\
\text { South } \\
\text { West } \\
\text { Total }\end{array}$ & $\begin{array}{r}+40 \\
-122 \\
-760 \\
-842\end{array}$ & $\begin{array}{r}+53 \\
-275 \\
-415 \\
-637\end{array}$ & $\begin{array}{r}+67 \\
-790 \\
-472 \\
-1,195\end{array}$ & $\begin{array}{r}+146 \\
-813 \\
-634 \\
-1,302\end{array}$ & $\begin{array}{r}+50 \\
-1,100 \\
-475 \\
-1,525\end{array}$ \\
\hline \multicolumn{6}{|c|}{$\begin{array}{l}\text { NORTHEAST } \\
\text { net exchange with }\end{array}$} \\
\hline $\begin{array}{l}\text { Midwest } \\
\text { South } \\
\text { West } \\
\text { Total }\end{array}$ & $\begin{array}{l}-40 \\
-314 \\
-285 \\
-639\end{array}$ & $\begin{array}{l}-53 \\
-438 \\
-224 \\
-715\end{array}$ & $\begin{array}{r}-67 \\
-964 \\
-311 \\
-1,342\end{array}$ & $\begin{array}{r}-146 \\
-945 \\
-518 \\
-1,609\end{array}$ & $\begin{array}{r}-50 \\
-737 \\
-234 \\
-1,022\end{array}$ \\
\hline
\end{tabular}


regions in the 1960's. The South has gained immigrants from the West, Midwest, and the Northeast since 1970. Two of the three fastest growing states, Texas and Florida, are in the South. The third is California.

In areas where a large number of immigrants are of the home-buying age, the housing construction increase is accompanied by an increase in the mercantile service sector. Convenience stores, shopping malls, and other retail stores are built to service the increasing population. The West and the South are projected to experience a $50 \%$ and $40 \%$ increase, respectively, in population over the age of twenty. This trend means that more people will be renting and buying housing in these regions, increasing the mercantile service sector.

\subsubsection{The Legis lative Atmosphere}

The most difficult area of influence to project is the qualitative area of legislative atmosphere. Essays can be developed describing various political atmospheres concerning the topic. Impacts of each political atmosphere are then assessed in the various scenarios. An essay concerning tax reform, the national debt, and the trade deficit is developed below.

By the time Reagan took office in 1980, political conservatism had become the norm. Reagan's domestic policies, aimed at reducing big government, and the national debt, and implementing supply-side economics have received widespread national support. As the Reagan administration faces the mid 1980's, major domestic concerns in washington D.C. are tax reform, the national debt, and the trade deficit. Tax reform has strong support in Congress. Major issues include closing the tax loop holes and shifting more of the tax burden to business. Tax reform will probably be accomplished and have long range effects into the twenty-first century. The tax shelters that aided the office building boom of the 1980's will disappear. Businesses will have less incentive to invest in new buildings and real estate.

"But because real estate plays such an important role in the nation's economy, real estate professionals such as syndicators and other sponsors of capital investment will continue to do business and adapt to changes." (Singer and Hirschfeld 1986.) 
Business will have to start investing in real estate itself and not in real estate for tax benefits.

The U.S. trade balance is experiencing the largest deficit in history. The large influx of foreign products has decreased demand for American products. The American manufacturing industry is losing significant shares of the U.S. market, hurting the U.S. economy and indirectly affecting the building industry and, therefore, the energy investment market. The concern that America is no longer competitive with the rest of the world is generating support for trade legislation aimed at protecting American manufacturing. The problem is sizeable and complex, but reduction in the trade deficit is expected by 2000 .

A third concern which has received scrutiny in Washington, D.C., is the national debt. Despite the current administration's attempts, the national debt has soared with little or no sign of decreasing. The large national debt crowds out investment monies that could be used for business. Congress continues to be concerned by the national debt and this concern, along with its legislative actions, will continue well into the twenty-first century. The size of the debt prohibits any quick remedies. Although actions will be taken to reduce it, the debt will continue to crowd out investments.

\subsubsection{Economic Trends Examined}

Economic trends are very much a function of legislative action and demographic trends. The economic descriptors discussed in this section are based on the discussions of the previous two sections.

The increasing numbers of people in the South and the West will promote a regional shift in the industrial sectors (see Table 4.2). The South is projected to have $47 \%$ increase in total employment from 1985 to 2030; the West, a $44 \%$ increase in total employment. The North Central and Northeast combined are projected to have only a $9.8 \%$ increase in total employment for the same time span (Kasarda, Irwin, and Hughes 1986).

The South is projected to increase employment in all sectors except agriculture, forestry, fisheries, and mining. The largest increase is projected to be in the finance, insurance, and real estate sector (80.3\%). Manufacturing 
TABLE 4.2. Shifting Industrial Sectors (Kasarda, et al. 1986)

(employment in thousands)

\begin{tabular}{|c|c|c|c|}
\hline Shifting Sectors & 1985 & 2030 & $\%$ change \\
\hline \multicolumn{4}{|l|}{ SOUTH } \\
\hline $\begin{array}{l}\text { Total } \\
\text { Primary } \\
\text { Secondary } \\
\text { Retail, wholesale } \\
\text { Finance, insurance, real estate } \\
\text { Services, government, utilities }\end{array}$ & $\begin{array}{r}37,994 \\
1,698 \\
8,118 \\
8,315 \\
1,957 \\
17,906\end{array}$ & $\begin{array}{r}56,008 \\
1,393 \\
10,259 \\
13,086 \\
3,528 \\
27,742\end{array}$ & $\begin{array}{r}47.4 \% \\
-18.0 \% \\
26.4 \% \\
57.4 \% \\
80.3 \% \\
54.9 \%\end{array}$ \\
\hline \multicolumn{4}{|l|}{ NORTH (North Central and Northeast) } \\
\hline $\begin{array}{l}\text { Total } \\
\text { Primary } \\
\text { Secondary } \\
\text { Retail, wholesale } \\
\text { Finance, insurance, real estate } \\
\text { Services, government, utilities }\end{array}$ & $\begin{array}{r}49,860 \\
1,647 \\
11,621 \\
10,757 \\
3,124 \\
22,711\end{array}$ & $\begin{array}{r}54,742 \\
1,462 \\
10,009 \\
11,632 \\
3,863 \\
27,776\end{array}$ & $\begin{array}{r}9.8 \% \\
-11.2 \% \\
-13.9 \% \\
8.1 \% \\
23.7 \% \\
22.3 \%\end{array}$ \\
\hline \multicolumn{4}{|l|}{ WEST } \\
\hline $\begin{array}{l}\text { Total } \\
\text { Primary } \\
\text { Secondary } \\
\text { Retai 1, wholesale } \\
\text { Finance, insurance, real estate } \\
\text { Services, government, utilities }\end{array}$ & $\begin{array}{r}21,688 \\
1,066 \\
4,097 \\
4,630 \\
1,289 \\
10,606\end{array}$ & $\begin{array}{r}31,267 \\
1,230 \\
5,290 \\
6,541 \\
2,452 \\
15,754\end{array}$ & $\begin{array}{l}44.2 \% \\
15.4 \% \\
29.1 \% \\
41.3 \% \\
90.2 \% \\
48.5 \%\end{array}$ \\
\hline
\end{tabular}

and construction will grow by $26.4 \%$, while retail and wholesale employment will grow by $57.4 \%$. Services, government, and utilities are projected to grow by $54.9 \%$.

Employment in the West is projected to increase in all industrial sectors; agriculture and mining, durable manufacturing, construction, nondurable manufacturing, utilities/communications, wholesale trade, retail trade, finance insurance and real estate, and services. The largest increase is projected to be in the finance, insurance, and real estate sector $(90.2 \%)$. Services and retail/wholesale employment are projected to grow by $48.5 \%$ and $41.3 \%$, respectively. 
The North Central and the Northeast regions of the United States are expected to lose jobs in the primary (agriculture, forestry, mining, and fisheries) and secondary (construction and manufacturing) industrial sectors. From 1985 to 2030, the North (North Central and Northeast) are expected to lose $11.2 \%$ of primary jobs and $13.9 \%$ of secondary jobs. The finance and services sector are projected to grow by $23.7 \%$ and $22.3 \%$, respectively.

The employment figures affecting the mercantile service building sector are in the retail and service areas. As the jobs grow in these sectors, more buildings will be constructed to take care of the demand. Increased construction will improve the energy investment market.

A second economic descriptor affecting the mercantile service sector is personal income. Increased personal incomes give a boost to demand for retail goods and services. Personal incomes are projected to rise in all of the four national regions through 2000. The South is projected to have the largest increase (23\%), followed by the North Central (19.3\%), the West (17.1\%), and then the Northeast (12.2\%). The Northeast will continue to have the highest per capita personal income of $\$ 14,963$ (American Demographics, 1985).

Other economic factors include interests rates, the national debt, foreign investments, and the trade balance. These factors work in combination to control the amount of money that is available for loans for. new businesses, business expansions and personal housing. Housing starts are a measure of the demand for retail and service establishments needed to support an increase in population.

The relationship of these economic variables is extremely complex and exact effects beyond the scope of this report. However, general trends in these areas are presented, based on the legislative atmosphere that was discussed in the previous section.

The large national debt and negative trade balance are two serious barriers to economic expansion, and therefore, to energy investments in the mercantile-service building sector. Although great strides in reducing the national debt and trade imbalance will probably take place, the sizes of these deficits are large enough to force some "crowding out" of investment monies 
that would have gone towards boosting the economy. The existing concern in Congress for the trade deficit is expected to motivate foreign countries to invest in America instead of importing to America. Foreign investments are expected to continue to increase, providing an outside source for investment monies. Interests have come down considerably in the 1980's. In order to stimulate the sluggish deficit-ridden economy, the prime interest rate is anticipated to decline slightly and remain under $10 \%$ through 2000 .

\subsubsection{Climatic Demands}

Although weather conditions for the national regions vary from year to year, the climate for these regions remains fairly constant. For the short time span under consideration for this scenario, the climates for the national regions are assumed to be constant. The climates for the region do vary, however, and this section provides a comparison of the needs for heating and cooling between the regions. Figure 4.3 shows the five weather zones in the

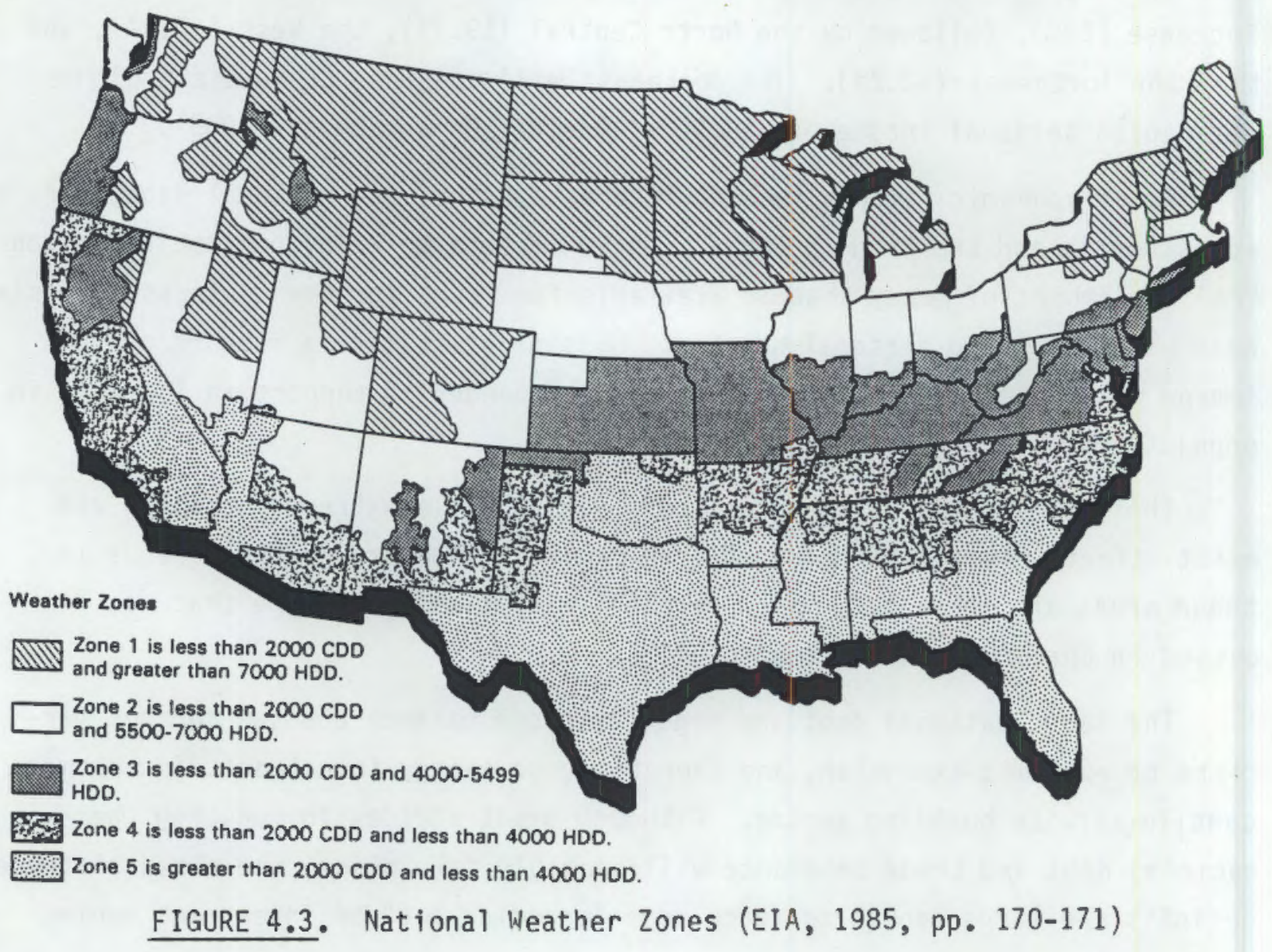


United States for heating degree days (HDD) and cooling degree days (CDD). The degree day normals are used to determine relative estimates of heating and cooling requirements for buildings. Each degree that the average temperature for a day is below $65^{\circ} \mathrm{F}$ produces one heating degree day. Each degree that the average temperature is above $65^{\circ} \mathrm{F}$ produces one cooling degree day. A large number of cooling degree days indicates a need for air conditioning in buildings. A large number of heating degree days may create concern for heating equipment.

As indicated on the weather zone map, the southern region of the United States has a greater need for air conditioning, especially in the Gulf coast and southern Atlantic states. The Northeast region is composed of Zone 1 and Zone 2 for CDD and HDD. Little demand for cooling energy exists in this region, but energy efficient heating equipment has a market here. The northern and mountainous sections of the North Central and West regions have little demand for energy expended on cooling compared to heating energy. The weather zone a building is located in affects the amount and type of available energy investments.

\subsection{THE SCENARID: THE ENERGY INVESTMENT MARKET IN THE MERCANTILE SERVICE, YEAR 2007}

Using the trends mentioned above, the demand for energy investments in the mercantile service sector is projected from a baseline in the early 1980's. Once energy investment demands have been established, the decision makers and the decision process are discussed.

The following scenario is set in the early 2000 's. The scenario is hypothetical, based on current projections for the year 2000 and the author's judgment.

January 2007. The service and retail sector of the national economy is riding the crest of an economic wave whose swells began in the 1970 's. The number of jobs in this sector have increased substantially in the past twenty years, and the trend is projected to continue for another 25 years. The total number of service and retail 
jobs have grown by an average of $25 \%$ since 1985 for each of the four major census regions (Northeast, North Central, South, and West). A $40 \%$ average increase is predicted through the year 2030 .

This increase in employment has placed a demand on the construction and retrofitting of buildings in the mercantile service building sector. Table 4.3 shows the increase in total square footage for the mercantile-service building sector. This building sector has grown from a total of 10,427 million square feet in 1983 to 12,304 million square feet last year, 2006; an 18\% increase. Most of the growth has been in the South, following the population migration trends of the past 30 years. The southern mercantile service building sector has added 307 million square feet to its building stock, an $8 \%$ increase since 1983. The West has increased its mercantile building stock by $5 \%$ or 66 million square feet. These two regions of the country have experienced the most population growth for the past 35 years.

TABLE 4.3. Total Square Footage in the Mercantile-Service Building Sector 1983 to 2006

\begin{tabular}{|c|c|c|c|}
\hline Region & 1983 & 2006 & $\%$ Change \\
\hline South & 3,843 & 307 & $8 \%$ \\
\hline West & 1,325 & 66 & $5 \%$ \\
\hline Northeast & 2,040 & 61 & $3 \%$ \\
\hline North Central & 3,219 & 64 & $2 \%$ \\
\hline Total & 10,427 & 12,304 & $18 \%$ \\
\hline
\end{tabular}

The North Central and Northeast regions have grown the least. The North Central region's mercantile service building stock has only grown by $2 \%$ or 64 million square feet. The Northeast region's stock has grown by $3 \%$ since 1983 and has added 61 million square feet to its inventory.

These numbers have had a large impact on the investment amounts made in energy efficient heating, cooling, and lighting systems. In 
the past ten years, concern has been generated about the efficient use of our national energy. Energy efficiency is seen as a sound business investment.

The energy systems in the large retail businesses that predominate the suburban and central city shopping districts are designed to meet the special requirements of the retail industry. The emphasis in energy usage is on the comfort of the customer and creating a pleasant shopping climate. The efficient use of energy in this situation, besides being a technical accomplishment, is an exercise in social behavior. The retail sector has done extensive research into how to best display their wares to appeal to the different types of shoppers. The lighting and climate control systems have been designed to optimize the selling of products. For example, retailers of winter clothing, including expensive furs and coats, have found that a cooler temperature in their winter clothing department facilitates the sales of winter clothing. The appropriate use of light on displays, bright lights tinted with hot colors for summer displays and soft glowing lights for winter displays, have also been discovered to increase sales.

The behavioral aspect of energy systems in the retail sector increases the amount of energy that is used, but the efficiency of this energy use has been improved with new technologies. The newest heating and cooling systems monitor the building climate constantly, making adjustments for different sales departments and working hours. Up-to-date lighting systems are designed with energy efficient bulbs that are appropriate for the varying displays. The best energy saving technologies have been those that are not subject to behavioral aspects. Furnaces, air conditioners, and building envelope technologies (roofing, windows, etc.) have been redesigned for specific needs and climates.

The largest increase in the number of mercantile service buildings has been in the South. Most of the construction has been in weather zone 5, placing an emphasis on cooling units which can 
efficiently help alleviate the hot, muggy summers of the South. The West, Tike the South, has been expanding its mercantile service building sector. The most populated areas of the West are in the warmer weather zones of 3 and 4 ; but geographically, the West enconpasses all five weather zones. The variety of Western climates allows for all types of energy efficient technologies. For the regions of the West with dry climates, water evaporators have been designed for cooling purposes. The South and the West have had the greatest population growth for the past 35 years. For this reason, the building stock is relatively new and retrofits are a small percentage of the energy investment market.

The least amount of growth in the mercantile service sector has been in the North Central and Northeast sections of the country. The North Central region covers the three coolest weather zones and energy efficient technology for heating purposes is more in demand. For the Northeast, the largest concentration of mercantile buildings is in weather zone 3; but the cooler zones of 1 and 2 cover more geographic territory. The buildings of the North Central and Northeast regions are the oldest in the nation. The economic growth of the South and west has limited the number of new buildings constructed in the northern part of the nation. Although new construction is being added, a strong market for retrofits exists in these regions.

The ownership and organizational structure of the owning entity are also important factors influencing energy investment decisions. The majority of the buildings are part of a corporate chain or are a franchise. Among large retail department stores, $98 \%$ of these stores are franchises or part of a chain. The decision process in these corporations involves a "buying center" which usually includes personnel with technical expertise; architects, designers, and engineers. Recent attitudinal surveys of energy investment decision makers point to the architects and designers as the innovators in using new technology. The top level management personnel were found 
to be less innovative and more concerned with already proven technologies. New energy efficient building technologies can more effectively be transferred to those innovative designers whom the top management depend on for competent choices. These technical people are not just in-house personnel, but work for architectural and design consulting firms.

The rest of the mercantile service sector is composed of partnerships and individual owners. In these cases the "buying center" is usually somewhat smaller. The owner or partners may play a larger role in the decision to invest in energy efficient equipment. Since the owners are more involved in the decision process, it is important that they reatize the benefits of new technologies. However, it is still important to transfer the technical information to the manufacturers and contractors. The smaller "buying center" usually obtains its information from these sources.

\subsection{INTRODUCTION DF UNCERTAIN EVENTS AND THEIR IMPACT}

The projections made in the scenario were based on the trends established in sections 4.2. These trends are the expected trends and do not take into account changes in them. This section alters the assumptions the scenarios were based on and discusses the impact of the new assumptions.

The most variable area of influence is probably the legislative atmosphere. As discussed above, a lot of concern exists in the U.S. Congress and among the American people for the national debt, the trade deficit, and tax reform. It was assumed above that the national debt and the trade deficit would be acted upon and reduced slowly. Consider the national debt continues to climb. The increasing national debt will "crowd out" potential investment monies. Interest rates will began to climb. This reaction to the national deficit will slow construction of residential homes and nonresidential buildings. Fewer residential homes means fewer mercantile-service businesses are needed to support the diminishing residential sector. Growth of the energy investment market among the mercantile-service sector will slow all across the nation. The slow population growth areas, such as the Northeast and North 
Central, will be especially hard hit. Energy investment decision makers will become more cautious in uncertain times, unwilling to invest in new technologies.

An unchecked foreign trade deficit would have similar effects on the energy investment market. More imports means less products being produced in the States. The decrease in manufacturing will cause unemployment and a decrease in the personal income of high manufacturing areas. The loss in personal spending income would be felt in the mercantile-service sector and decrease the demand for its products. A decline in construction in this sector would ensue. If the foreign trade deficit remained unchecked the U.S. economy would probably adapt by shifting employment to nonmanufacturing sectors. Once the adaptation was made, the mercantile-service sector would respond positively.

Regional shifts in the energy investment market could be caused by shifting population migration patterns. Presentiy, the South and the West are attracting large numbers of people. California is the fastest growing state in the West. Caljfornia is also predicted to have a major earthquake in the near future. Let us suppose that major earthquakes strike California for a period of three years. While the buildings will need to be replaced, such adverse natural conditions could slow the population migration into the state. Initialty there would be a demand for energy investment technologies, but as the population growth shifted to more desirable regions, the energy investment market would ultimateiy decline.

Any unexpected changes in the areas of influence can change scenario outcomes. Scenario construction takes into consideration the likelihood of such events happening. Scenarios also consider improbable events that would have a significant impact on the areas of influence. The events mentioned above are intended to demonstrate the usefulness of scenarios. 


\subsection{RECOMMENDATIONS FOR FUTURE RESEARCH}

The scenario developed in the previous section was based on an analysis and projection of the economic and demographic descriptors mentioned in Sections 2.0 and 3.0. The example scenario was based on the available literature. For this reason the scenario is more qualitative than quantitative. Detailed national data on the physical descriptors of buildings effecting energy investments are available in the Nonresidential Buildings Energy Consumption Survey (NBECS). However, the NBECS does not provide an integrated data source on both the physical descriptors and the legal descriptors affecting energy investments. The Dodge division of the McGraw-Hill Inc. also provides extensive data on the physical descriptors of buildings, but it too lacks data on the legal descriptors mentioned in this report.

Another gap in the literature is detailed information on the attitudes of the investment decision maker. Literature does exist on organizational decision making and the factors that affect the decision process. However, no studies were found that attempt to characterize the attitudinal composition of present building owners and decision makers. A national study on this subject could prove to be difficult, but a study or series of regional studies on decision makers' attitudes and their energy investments could add valuable information to present knowledge.

The following sections outline research projects designed to fill in these gaps in the available information. These proposed projects cover scenario construction methods, descriptors of the nonresidential building sector, and attitudes of energy investment decision makers. The data from each of these projects could aid in the development and prioritizing of research and development agendas.

Scenarios of future compositions of decision makers and the extent of their influence on energy conservation investment decisions will aid in directing new technologies to the appropriate market segments. Accurate projections of decision maker compositions and the building stock they control depend on the availability of up-to-date information and proven scenario construction methods. 


\subsection{ENERGY INVESTMENT BUILDING SURVEY}

A data base to aid in the projections of energy investment market in the nonresidential building sector will need to include data on the physical and legal descriptors mentioned in Section 2.1. Much of this information is already available in the NBECS, and it may be possible to include part of the data from this triennial survey in the proposed data base. The key information missing is data on the legal descriptors affecting the energy investment decision maker.

Data are available from the United States Government on the economic and demographic trends that affect the building market. Construction starts, personal income, interest rates, and the trade balance are a few variables that could be regularly updated from government publications. Tracking population migrations can be done through the IRS. Tax returns represent approximately $90 \%$ of the population and changes of address can be monitored annually (Rogerson and Plane 1985).

We propose a database which would

- track demographic trends that influence the nonresidential building sector

- track economic variables that influence the nonresidential building sector

- characterize the potentiat for energy investments in the nonresidential building sector.

These objectives can be accomplished with the methodology outlined below.

- Collect data on economic descriptors which affect the building sector. Data are readily found in government publications.

- Collect data on population growth and migrations. This information is available from the U.S. Bureau of the Census. A better source for tracking annual population movements is the IRS.

- Collect nationwide survey data on nonresidential buildings. The data should concern itself with information on the descriptors mentioned in Section 2. 
This proposed database could be regularly updated, possibly every three years, providing a continuous source of information used for planning purposes. The data base could also be designed to be expanded and include other data necessary.

\subsection{ATTITUDES OF THE NONRESIDENTIAL ENERGY INVESTMENT DECISION MAKER}

The organizational decision making and attitudinal literature supports the proposal of the following research project. The importance of decision processes and attitudes of decision makers has been shown for understanding the acceptance of new technologies. This research proposal involves a psychographic study of nonresidential energy investment decision makers. Psychographics is a marketing technique used to develop a psychological profile of a population, in this case, energy investment decision makers. Once attitudes have been profiled, the relationship between these attitudes and energy jnvestments would be examined. The objectives of this study would be to

- characterize the regional attitudinal composition of nonresidential energy investment decision makers

- explore the relationship between specific attitudes and the amount and types of energy investment.

To accomplish these objectives the following general methodology is proposed.

- Construct a survey instrument that includes questions on attitudes, energy investments made, and building descriptors (legal and physical).

- Develop a statistical sampling procedure for the region of interest.

- Conduct telephone and in person interviews with energy investment decision makers.

- Analyze results.

A series of regional surveys on decision maker attitudes would be the best way to characterize the national attitudinal picture. 


\subsection{BATTELLE'S SCENARIO INPUTS TO CORPORATE STRATEGY (BASICS)}

Battelle's Scenario Inputs to Corporate Strategy (BASICS) was developed as a method to forecast long-range, multifactor, and highly uncertain conditions. It is a method that combines group dynamics, expert judgment, trends analysis, and cross-impact analysis to generate scenarios.

The BASICS package can be used to construct a series of scenarios of the nonresidential energy investment market to aid in the planning of research and development agendas. These scenarios could be constructed from available data or with data obtained in the previous research proposals. The preparation of these scenarios would involve the following steps

- definition of topic and identification of areas of influence

- preparation of trend analysis essays

- cross-impact analysis of descriptor states

- selection of likely scenarios and relevant uncertain event scenarios from the cross-impact analysis.

The BASICS package has a variety of options available at various pricing schemes. The package includes BASICS software package, data and descriptor essays, and explanatory workshops. 


\section{REFERENCES}

Bruneau, Carol. 1985. An Overview of Perceived Risk in Consumer Behavior, unpublished paper, Oklahoma State University, Dept. of Marketing.

"Construction Outlook for 1985." 1983. Construction Review, (March/April) 29 no. 2:3-11.

Dinan, Terry M. 1986. A Method for Analyzing the Market for Conservation Retrofit Technologies in the Commercial Sector. Oak Ridge National Laboratory, Oak Ridge, Tennessee.

Dornbusch, David M. and Co. 1984. "Centralized Decision Making Process." Deliverable \#3, Program Analysis, Task G. Market for "Centralized Decision Maker: Commercial Subprogram, prepared for Bonneville Power Administration.

Energy Information Administration. 1985. Nonresidential Buildings Energy Consumption Survey: Characteristics of Commercial Buildings 1983. DOE/EIA0246(83). Washington, D.C.

Feldman, S. Undated a. "Determinants of Interest in New Energy Reduction Projects Among Commercial and Industrial Ratepayers." ARBOR, Inc., Philadelphia, Pennsylvania.

George, S., J. da Silva, and M. R. McRae. 1986. Impact of Short-Term Leases on Conservation Investments of Commercial Landlords and Tenants for Bonneville Power Administration. Xenergy, Inc., San Francisco, California.

Hage, Jerald. 1980. Theories of Organizations. New York: John Wiley and Sons, Inc.

Hall, Richard. 1982. Organizations: Structure and Process. Prentice-Hall, Inc., Englewood Cliffs, New Jersey.

Hutt, M., and T. Speh. 1981. Industrial Marketing Management. The Dryden Press, CBS College Publishing, Hinsdate, Illinois, pp. 79-90.

Kasarda, J., M. Irwin, and H. Hughes, 1986. "The South is Stitl Rising." American Demographics, (June) 8:32-38.

Keinan, G., and E. Meir, T. Gonme-Nemirovsky. 1984. "Measurement of Risk Takers' Personality." Psychological Reports 55:163-67.

Lazo, H. 1960. "Emotional Aspects of Industrial Buying." Proceedings of the American Marketing Association. American, R. S. Hancock, ed. Marketing Association, Chicago, IlTinois, p. 265.

Miles, R., C. Snow, and J. Pfeffer. 1974. "Organizational Envi ronment: Concepts and Issues." Industrial Relations, (October) 13 no. 3:244-64. 
Nieves, L. A., and J. M. Fang. 1986. Literature Review on Energy Conservation Investment in Non Residential Buildings. Pacific Northwest Laboratory, Richland, Washington.

Office of Technology Assessment (OTA). 1982. "Will Building Owners Invest in the Energy Efficiency of City Building?" In Energy Efficiency of Buildings in Cities. Washington, D.C.

"Regional Change in Population, Employment, and Income." 1985. American Demographics, (November) 7:58.

"Regiona1 Developments in Construction Activity." 1984. Construction Review, (Nov/Dec) 30 no. 6:4-13.

Rogerson, P., and D. Plane. 1985. "Monitoring Migration Trends." American Demographics, (February) 7:27-29, 47.

Singer, C., and J. Hirschfeld. 1986. "Real Estate Provides Investor Opportunities; Tax Reform Isn't Likely to Change Aggregate Benefits." National Rea? Estate Investor, (August) 28 no. 9:66.

Statistical Abstract of the United States. 1986. U.S. Department of Cormerce, Bureau of the Census, Washington, D.C.

Temple, Barker, and Sloane, Inc. 1984a. The Commercial Sector and Conservation Investment Decisions: Experiences and Motivations--A Literature Review. Lexington, Massachusetts.

Thompson, J. D. 1967. Organizations in Action. New York: MCGraw-Hill Book Company.

Watts, R. L., D. R. Johnson, S. A. Smith, and E. J. Westergard. 1985. Research Utilization in the Building Industry: Decision Model and Preliminary Assessment. Pacific Northwest Laboratory, Richland, Washington. 


\section{DISTRIBUTION}

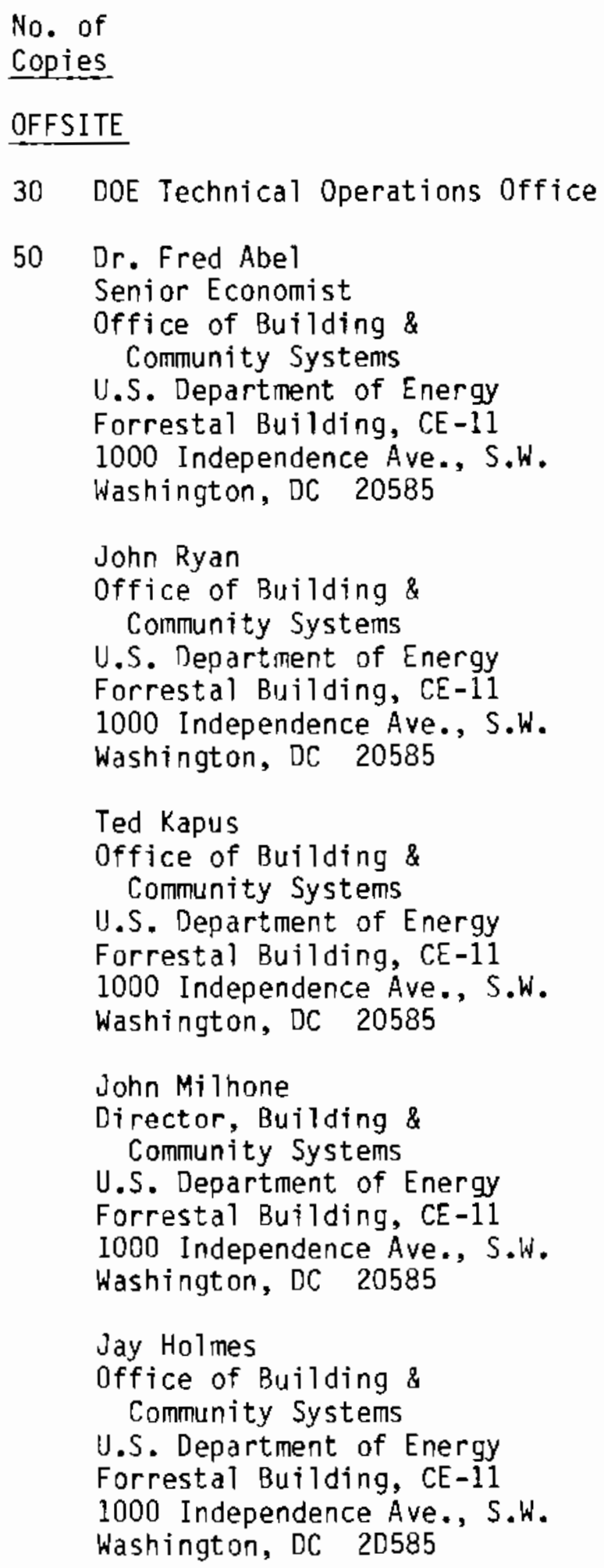

No, of

Copies

Terry Dinan

Oak Ridge National Laboratory

P.0. Box X

Oak Ridge, Tennessee 37831

Dr. Tom Anyos

Manager, Commercial Development

Electric Power Research

Institute

$3412 \mathrm{Hill}$ view Avenue

P.0. Box 10412

Palo Alto, CA 94303

Ken Kazmer

Manager, Building Systems Research

Gas Research Institute

8600 West Bryn Mawr Avenue

Chicago, IL 60631

Jerome Lamontagne

Building 120

Brookhaven National Laboratory Upton, NY 31973

ONSITE

DOE Richland Operations Office

J. J. Sutey

22 Pacific Northwest Laboratory

C. L. Bruneau (5)

L. J. Davis (I)

B. A. Garrett

S. A. Harkreader (5)

D. L. Ivey

B. L. Mohler

R. 0. Weijo

Publishing Coordination MH (2)

Technical Report Files (5) 
